\title{
Probiogenomics of Lactobacillus delbrueckii subsp. lactis CIDCA 133: In Silico, In Vitro, and In Vivo Approaches
}

\author{
Luís Cláudio Lima de Jesus ${ }^{1}$, Mariana Martins Drumond ${ }^{2}$, Flávia Figueira Aburjaile ${ }^{1,3}{ }^{\mathbb{D}}$, Thiago de Jesus Sousa ${ }^{1}$, \\ Nina Dias Coelho-Rocha ${ }^{1}{ }^{10}$, Rodrigo Profeta ${ }^{1}$, Bertram Brenig ${ }^{4}\left(\mathbb{D}\right.$, Pamela Mancha-Agresti ${ }^{5}$ \\ and Vasco Azevedo ${ }^{1, *}$ \\ 1 Laboratório de Genética Celular e Molecular (LGCM), Departamento de Genética, Ecologia e Evolução, \\ Instituto de Ciências Biológicas, Universidade Federal de Minas Gerais (UFMG), \\ Belo Horizonte 31270-901, Brazil; lc.luiis@yahoo.com.br (L.C.L.d.J.); faburjaile@gmail.com (F.F.A.); \\ thiagojsousa@gmail.com (T.d.J.S.); ninadias008@gmail.com (N.D.C.-R.); profeta.biotec@gmail.com (R.P.) \\ 2 Centro Federal de Educação Tecnológica de Minas Gerais (CEFET/MG), \\ Departamento de Ciências Biológicas, Belo Horizonte 31421-169, Brazil; mmdrumond@gmail.com \\ 3 Laboratório de Flavivírus, Instituto Oswaldo Cruz, Fundação Oswaldo Cruz, Rio de Janeiro 21040-360, Brazil \\ 4 Institute of Veterinary Medicine, University of Göttingen, D-37077 Göttingen, Germany; bbrenig@gwdg.de \\ Faculdade de Minas-Faminas-BH, Medicina, Belo Horizonte 31744-007, Brazil; p.mancha.agresti@gmail.com \\ * Correspondence: vasco@icb.ufmg.br
}

Citation: de Jesus, L.C.L.; Drumond, M.M.; Aburjaile, F.F.; Sousa, T.d.J.; Coelho-Rocha, N.D.; Profeta, R.; Brenig, B.; Mancha-Agresti, P.; Azevedo, V. Probiogenomics of Lactobacillus delbrueckii subsp. lactis CIDCA 133: In Silico, In Vitro, and In Vivo Approaches. Microorganisms 2021, 9, 829. https://doi.org/ $10.3390 /$ microorganisms 9040829

Academic Editor: Mariantonietta Succi

Received: 10 March 2021

Accepted: 30 March 2021

Published: 14 April 2021

Publisher's Note: MDPI stays neutral with regard to jurisdictional claims in published maps and institutional affiliations.

Copyright: (c) 2021 by the authors. Licensee MDPI, Basel, Switzerland. This article is an open access article distributed under the terms and conditions of the Creative Commons Attribution (CC BY) license (https:/ / creativecommons.org/licenses/by/ $4.0 /)$.

\begin{abstract}
Lactobacillus delbrueckii subsp. lactis CIDCA 133 (CIDCA 133) has been reported as a potential probiotic strain, presenting immunomodulatory properties. This study investigated the possible genes and molecular mechanism involved with a probiotic profile of CIDCA 133 through a genomic approach associated with in vitro and in vivo analysis. Genomic analysis corroborates the species identification carried out by the classical microbiological method. Phenotypic assays demonstrated that the CIDCA 133 strain could survive acidic, osmotic, and thermic stresses. In addition, this strain shows antibacterial activity against Salmonella Typhimurium and presents immunostimulatory properties capable of upregulating anti-inflammatory cytokines $I l 10$ and $T g f b 1$ gene expression through inhibition of $N f k b 1$ gene expression. These reported effects can be associated with secreted, membrane/exposed to the surface and cytoplasmic proteins, and bacteriocins-encoding genes predicted in silico. Furthermore, our results showed the genes and the possible mechanisms used by CIDCA 133 to produce their beneficial host effects and highlight its use as a probiotic microorganism.
\end{abstract}

Keywords: genomic characterization; phylogenomic; probiotic; Lactobacillus delbrueckii; acid and bile tolerance; $N f k b 1$ gene expression; surface proteins; bacteriocin

\section{Introduction}

Lactobacillus is a highly diverse taxonomic group of Gram-positive microorganisms, rod or coccobacilli-shaped, members of lactic acid bacteria (LAB), facultatively anaerobic [1,2], and able to produce lactic acid as the primary metabolic end product of carbohydrate fermentation $[2,3]$. These microorganisms can be found and isolated from different ecological niches (e.g., vegetables, fermented products, gastrointestinal and vaginal tracts of humans and animals) where there is a high carbohydrate availability [4].

Many Lactobacillus strains have a probiotic profile and, thus, present functional characteristics beneficial to the host, such as their immunomodulatory and anti-inflammatory properties [5,6], and its effectiveness on the treatment of Crohn's disease and ulcerative colitis [7,8], intestinal mucositis [9,10], and enteric infections [11,12]. However, it should be emphasized that the beneficial effects of probiotics on the host are strain-dependent $[13,14]$ and cannot be generalized.

The Lactobacillus strains described as probiotics, with many potential benefits attributed to the host health, and general commercial and biotechnological potential, are 
now being studied in the genomic field [15-17]. The Lactobacillus genome analysis has contributed to more detailed characterization in terms of the identification and function of gene products and possible molecular mechanisms related to the probiotic effects attributed to these bacteria [18], as well as their animal and human consumption-related safety $[16,19]$. However, unlike other LAB species, few studies have focussed on Lactobacillus delbrueckii probiogenomics, and the few genomic data are mainly obtained from bulgaricus subspecies $[20,21]$.

Lactobacillus delbrueckii subsp. lactis CIDCA 133 (CIDCA 133) is a new potential probiotic strain of Lactobacillus delbrueckii subsp. lactis species isolated from raw cow's milk [22]. According to previous in vitro studies, this strain has shown the ability to tolerate high concentrations of bile salts [23] and antagonistic action against the pathogenic enterohemorrhagic Escherichia coli (EHEC) [24] and bacteria causing food contamination, such as Pseudomonas aeruginosa [22]. Furthermore, this probiotic strain modulated cell response in both monocyte-derived dendritic cells and murine macrophages (RAW 264.7 cells) infected with Bacillus cereus [25] and Citrobacter rodentium [26] through enhancing the TNF- $\alpha$ and ROS production, respectively. This probiotic strain was also able to survive and grow in the presence of enterocyte-derived antimicrobial molecules, such as $\beta$-defensins [27,28]. Additionally, it was also reported that the administration of fermented milk by CIDCA 133 to $\mathrm{BALB} / \mathrm{c}$ mice prevented the inflammatory response and histopathological damage caused to the intestinal mucosa after 5-Fluorouracil $(300 \mathrm{mg} / \mathrm{Kg})$ chemotherapy administration [10].

Although promising results have been previously obtained in pre-clinical studies regarding this strain, there is little information about the genetic factors related to its protective action mechanisms; therefore, this work aims to characterize the L. delbrueckii CIDCA 133 strain through a probiogenomics approach. The genomic data (in silico) will allow the potential molecular mechanisms involved with the probiotic properties and immunomodulatory capacity for this strain to be known and reported in vitro and in vivo studies.

\section{Materials and Methods}

\subsection{Bacteria Strain and Growth Conditions}

Lactobacillus delbrueckii subsp. lactis CIDCA 133 belongs to the culture collection of the Centro de Investigación y Desarrollo en Criotecnología de Alimentos (CIDCA) of the Universidad Nacional de La Plata, Argentina. This strain was deposited at the Bacteria Collection from Environment and Health (CBAS) of the Oswaldo Cruz Foundation (FIOCRUZ) (Accession number: CBAS 815). CIDCA 133 was cultivated in de Man, Rogosa, and Sharpe (MRS) broth (Kasvi, São José dos Pinhais, Brazil) for $16 \mathrm{~h}$ at $37^{\circ} \mathrm{C}$.

\subsection{CIDCA 133 Identification by MALDI-TOF Biotyper ${ }^{\circledR}$}

After growth, CIDCA 133 was plated using a sterile plastic loop on MRS agar plates (São José dos Pinhais, Brazil) and incubated at $37^{\circ} \mathrm{C}$ for $48 \mathrm{~h}$. he colonies' identification using the MALDI-TOF Biotyper ${ }^{\circledR}$ Mass Spectrometry (Brukker Daltoniks, Billerica, MA, USA) was performed according to the manufacturer's instructions.

\subsection{Genomic and Plasmid DNA Extraction}

CIDCA 133 genomic DNA extraction was performed through mechanical lysis followed by purification with a phenol solution (phenol:chloroform:isoamyl alcohol 25:24:1, $v / v$, respectively), precipitation with ethanol $70 \%$ and sodium acetate $3 \mathrm{M}$, and suspension in DNase and RNase-free water, according to the protocol established by Sachinandan et al. [29]. According to the manufacturer's instructions, the plasmid extraction was performed using the Pure Link ${ }^{\mathrm{TM}}$ Quick Plasmid Miniprep Kit (Invitrogen, Carlsbad, CA, USA).

\subsection{Genome Sequencing, Assembly, and Annotation}

CIDCA 133 whole genome sequence was performed using the HiSeq 2500 platform (Illumina, San Diego, CA, USA), paired-end libraries $(2 \times 150 \mathrm{bp})$. The quality assessment 
of the reads was performed using FastQC [30]. De novo genome assembly was performed using the Edena assembler (v. 3.13) [31]. The assembly quality was verified using QUAST (Quality assessment tool) [32]. The contigs were ordered and oriented through the CONTIGUATOR (v. 2.74) [33], using the whole genome of L. delbrueckii subsp. bulgaricus ND02 (RefSeq: NC_014727.1) as a reference. The remaining gaps were closed using GapBLASTER (v. 1.1.2) [34], GenomeFinisher (v.1.4) [35] and QIAGEN CLC Genomics Workbench 20 (v. 20.0.4) [36].

The protein encoding-ORFs were automatically annotated using the Prokaryotic Genome Annotation Pipeline (PGAP) from the National Center for Biotechnology (NCBI) [37]. The genome and plasmid sequences were deposited in the NCBI (Access Number: CP065513 and CP065514, respectively).

\subsection{In Silico Analysis}

\subsubsection{Plasmid Identification}

The presence of plasmids was searched using the PlasmidFinder (https://cge.cbs.dtu. $\mathrm{dk} /$ services/PlasmidFinder/) (accessed on 15 December 2020) [38]. The circular map of the plasmid was obtained by SnapGene ${ }^{\circledR}$ software (v. 5.1.3.1).

\subsubsection{Phylogenomic Analysis}

For comparative genomic analysis, 26 complete genomes of Lactobacillus delbrueckii strains from the NCBI database were used (Table 1). The taxonomic analysis to compare whether or not the strains belonged to the same species was carried out by calculating the Average Nucleotide Identity (ANI) by Blast (ANIb) performed within the JSpecies Web Server [39]. ANIb values were visualized as a heatmap. Genomes with ANI > 95\% were considered the same species.

Table 1. Complete genomes of Lactobacillus delbrueckii strains obtained from NCBI used in comparative analysis.

\begin{tabular}{|c|c|c|c|c|}
\hline $\mathbf{N}^{\mathbf{o}}$ & Bacteria Strain & Genome Access & Size $(\mathbf{M b})$ & GC\% \\
\hline 1 & L. delbrueckii P3MRA & NZ_CP045604.1 & 1.87 & 49.70 \\
\hline 2 & L. delbrueckii TS1-06 & NZ_CP046390.1 & 1.85 & 49.80 \\
\hline 3 & L. delbrueckii subsp. bulgaricus LJJ & NZ_CP049052.1 & 1.89 & 49.50 \\
\hline 4 & L. delbrueckii subsp. bulgaricus KLDS1.1011 & NZ_CP041280.1 & 1.89 & 49.80 \\
\hline 5 & L. delbrueckii subsp. bulgaricus MN-BM-F01 & NZ_CP013610.1 & 1.88 & 49.70 \\
\hline 6 & L. delbrueckii subsp. bulgaricus KLDS1.0207 & NZ_CP032451.1 & 1.87 & 49.80 \\
\hline 7 & L. delbrueckii subsp. bulgaricus DSM 20080 & NZ_CP019120.1 & 1.87 & 49.80 \\
\hline 8 & L. delbrueckii subsp. bulgaricus ND04 & NZ_CP016393.1 & 1.86 & 49.60 \\
\hline 9 & L. delbrueckii subsp. bulgaricus ACA-DC 87 & NZ_LT899687.1 & 1.86 & 49.80 \\
\hline 10 & L. delbrueckii subsp. bulgaricus L99 & NZ_CP017235.1 & 1.85 & 49.70 \\
\hline 11 & L. delbrueckii subsp. bulgaricus 2038 & NC_017469.1 & 1.87 & 49.70 \\
\hline 12 & L. delbrueckii subsp. bulgaricus ATCC 11842 & NC_008054.1 & 1.86 & 49.70 \\
\hline 13 & L. delbrueckii subsp. bulgaricus ATCC BAA-365 & NC_008529.1 & 1.86 & 49.70 \\
\hline 14 & L. delbrueckii subsp. bulgaricus ND02 & NC_014727.1 & 2.13 & 49.59 \\
\hline 15 & L. delbrueckii subsp. delbrueckii NBRC 3202 & NZ_AP019750.1 & 1.91 & 50.10 \\
\hline 16 & L. delbrueckii subsp. delbrueckii TUA4408L & NZ_CP021136.1 & 2.01 & 49.90 \\
\hline 17 & L. delbrueckii subsp. delbrueckii KCТC 13731 & NZ_CP018216.1 & 1.91 & 50.00 \\
\hline 18 & L. delbrueckii subsp. indicus JCM 15610 & NZ_CP018614.1 & 2.02 & 49.37 \\
\hline 19 & L. delbrueckii subsp. jakobsenii DSM 26046 & NZ_CP018218.1 & 1.89 & 50.10 \\
\hline 20 & L. delbrueckii subsp. lactis KCСM 34717 & NZ_CP018215.1 & 2.26 & 49.10 \\
\hline 21 & L. delbrueckii subsp. lactis KCTC 3034 & NZ_CP023139.1 & 2.24 & 49.00 \\
\hline 22 & L. delbrueckii subsp. lactis 1 & NZ_LS991409.1 & 2.05 & 49.60 \\
\hline 23 & L. delbrueckii subsp. lactis КСТС 3035 & NZ_CP018156.1 & 1.97 & 50.00 \\
\hline 24 & L. delbrueckii subsp. lactis NWC_1_2 & CP029250.1 & 2.26 & 48.58 \\
\hline 25 & L. delbrueckii subsp. lactis DSM 20072 & NZ_CP022988.1 & 2.17 & 49.00 \\
\hline 26 & L. delbrueckii subsp. sunkii JCM 17838 & NZ_CP018217.1 & 2.00 & 50.10 \\
\hline
\end{tabular}




\subsubsection{Subcellular Localization of CIDCA 133 Proteins}

The prediction of subcellular localization of CIDCA 133 proteins was performed using the SurfG+ software, which classifies proteins based on the presence (secreted proteins) or absence (cytoplasmic proteins) of a signal peptide, transmembrane helices (membrane proteins), and signal retention (proteins that are covalently or transiently bound to the cell wall) [40].

\subsubsection{Functional Annotation of CIDCA 133 Proteins}

For functional characterization, the protein sequences predicted in the CIDCA 133 genome were submitted to the GO FEAT (Gene Ontology Functional Enrichment Annotation Tool) (http:/ / computationalbiology.ufpa.br/gofeat/) (accessed on 8 January 2021) [41].

\subsubsection{Cell Adhesion-Related Genes}

The CIDCA 133 genes' prediction involved in the adhesion mechanisms was evaluated through Vaxign (Vaccine Design) (v.2beta) (http://www.violinet.org/vaxign/) (accessed on 17 January 2021) [42]. A score of 0.6 was selected as the criteria to analyze which CIDCA 133 proteins (sub-located in the membrane, surface-exposed (PSE), or secreted) have a high adhesion capacity.

\subsubsection{Proteolytic Activity and Stress Tolerance-Related Genes}

The CIDCA 133 stress tolerance (acid, bile, thermal, and osmotic) and proteolytic system-related genes' prediction were based on literature data revision [43-48] for previously reported genes identified in probiotic bacteria involved with the above processes.

\subsubsection{Metabolic and Symbiotic Islands Prediction}

The Metabolic (MI) and Symbiotic (SI) Islands prediction in the CIDCA 133 genome was performed with GIPSy software (Genomic Island Prediction Software) (v.1.1.2) [49], using the Lacticaseibacillus rhamnosus GG (L. rhamnosus) genome (NZ_CP031290.1) as subjects. The Genomic Islands (GEIs) map was visualized using BRIG (BLAST Ring Image Generator) software (v. 0.95) [50].

\subsubsection{Bacteriocins Prediction}

Gene's prediction related to bacteriocins synthesis was performed by BAGEL4 (BActeriocin GEnome mining tooL) (http:/ /bagel4.molgenrug.nl/index.php) (accessed on 22 December 2020) [51].

\subsubsection{Protein-Protein Interactions Prediction}

For the potential biological functions of CIDCA 133 on human immunology, the prediction of interactions between CIDCA 133 and human proteins was carried out. The human protein sequence was mapped to KEGG pathways (toll-like receptor 2/4 nuclear factor карpa B (TLR2/4-NF-kB) pathway) and obtained from UniProt (UP000005640) (Table S1). The CIDCA 133 proteins with a high likelihood of adherence predicted by Vaxign ( $>0.6$ scores) were used. The protein-protein interaction was performed in InterSPPI [52]. The resulting interactions were filtered according to the 0.9765 score prediction (specificity of 0.99). The graphical interaction results were achieved by Cytoscape software [53].

\subsection{In Vitro Analysis}

2.6.1. Simulated Gastric Juice and Heat Stress Tolerance

The CIDCA 133 tolerance to acidic gastric juice simulated with pepsin solution (pH 3.0) was performed according to Singhal et al. [54]. Briefly, $3 \mathrm{~g} / \mathrm{L}$ of pepsin (Sigma-Aldrich, St. Louis, MO, USA) was diluted in $0.5 \%$ sterile $\mathrm{NaCl}$ (pH 3.0) (Vetec, Rio de Janeiro, Brazil). Subsequently, the cell pellet $\left(10^{8} \mathrm{CFU} / \mathrm{mL}\right)$ was washed twice with sterile and cold PBS $0.1 \mathrm{M}$ (pH 7.0) and suspended with $400 \mu \mathrm{L}$ of sterile $\mathrm{NaCl} 0.5 \%$ (pH 7.0). One hundred 
microliters of the culture was inoculated in $900 \mu \mathrm{L}$ of the pepsin solution (pH 3.0) and incubated at $37^{\circ} \mathrm{C}$ for $4 \mathrm{~h}$ with shaking (200 rpm) in a shaker (Labnet, Edison, NJ, USA)

For heat stress, the CIDCA 133 culture $\left(10^{8} \mathrm{CFU} / \mathrm{mL}\right)$ was centrifuged $(5000 \mathrm{rpm}$ for $10 \mathrm{~min}$ at $\left.4{ }^{\circ} \mathrm{C}\right)$, washed twice with sterile and cold PBS $0.1 \mathrm{M}(\mathrm{pH} 7.0)$, suspend with $1 \mathrm{~mL}$ of MRS broth, and incubated for $30 \mathrm{~min}$ to $65^{\circ} \mathrm{C}$ (a temperature of the simulated pasteurization process) [55]. As a control, $1 \mathrm{~mL}$ of CIDCA 133 was not submitted to heat stress.

Then, $100 \mu \mathrm{L}$ of each sample was collected after 0,2 , and $4 \mathrm{~h}$ (acid stress) and $30 \mathrm{~min}$ (heat stress) of incubation, and serially diluted (1:10) (acid stress: $10^{-8}$; heat stress: $10^{-7}$ ) in sterile-cold PBS 0.1 M (pH 7.0), plated on MRS agar (Kasvi, São José dos Pinhais, Brazil) and incubated at $37^{\circ} \mathrm{C}$ for $48 \mathrm{~h}$. The number of viable bacteria was determined by counting colony-forming units $(\mathrm{CFU} / \mathrm{mL})$ after incubation period.

\subsubsection{Osmotic Stress Tolerance}

For CIDCA 133 ability to tolerate different concentrations of sodium chloride $(\mathrm{NaCl})$, $150 \mu \mathrm{L}$ of the culture was inoculated in $15 \mathrm{~mL}$ of MRS broth containing different concentrations of $\mathrm{NaCl}(1 \%, 2 \%, 3 \%, 4 \%$, and 5\%) [56]. As a control, $150 \mu \mathrm{L}$ of CIDCA 133 was inoculated in $15 \mathrm{~mL}$ of MRS broth without $\mathrm{NaCl}$ supplementation. After $24 \mathrm{~h}$ of growth at $37^{\circ} \mathrm{C}$, the samples' absorbance was measured at O.D. $\cdot 600 \mathrm{~nm}$.

\subsubsection{Antibacterial Activity}

For this analysis, the indicator strains Shigella sonnei ATCC ${ }^{\circledR}$ 9290, Salmonella enterica serovar Typhimurium ATCC ${ }^{\circledR} 29630$, Enterococcus faecalis ATCC $^{\circledR} 19433$, Listeria monocytogenes ATCC ${ }^{\circledR} 15313$ were obtained from the American Type Culture Collection (ATCC) (Manassas, Virginia, EUA). Lactobacillus delbrueckii CNRZ327 and Lacticaseibacillus paracasei BL23 (L. paracasei BL23) belongs to the culture collection of the Institute Nacional de la Recherche Agronomique (INRA, Jouy-en-Josas, France). These strains were cultivated in MRS broth (Kasvi, São José dos Pinhais, Brazil) or BHI (Brain Heart Infusion) (Sigma-Aldrich, St. Louis, MO, USA) at $37^{\circ} \mathrm{C}$ for $24 \mathrm{~h}$.

Antibacterial activity of CIDCA 133 against these indicator strains was evaluated using CIDCA 133 cells-free supernatant (CFS), according to the method described by Somashekaraiah et al. [57], with some modifications. For this purpose, $100 \mathrm{~mL}$ of CIDCA 133 culture grown in MRS broth at $37^{\circ} \mathrm{C}$ for $24 \mathrm{~h}$ was centrifuged ( $5000 \mathrm{rpm}$ for $15 \mathrm{~min}$ at $4{ }^{\circ} \mathrm{C}$ ). Part of the cell-free supernatants (CFS) was kept with their initial acid $\mathrm{pH}$. Another was neutralized (nCFS) (pH 6.5) with 1.0 M NaOH (Vetec, Rio de Janeiro, Brazil). The CFS and nCFS aliquots were sterilized through a $0.22 \mu \mathrm{m}$ filter (Kasvi, São José dos Pinhais, Brazil). Then, $200 \mu \mathrm{L}$ of the indicator strains, previously grown in $\mathrm{BHI}$ broth at $37^{\circ} \mathrm{C}$ for $24 \mathrm{~h}$, was inoculated in $2 \mathrm{~mL}$ of the CIDCA 133 supernatant (CFS or nCFS). As a control, the indicator strains were grown in MRS broth. After $24 \mathrm{~h}$ incubation at $37^{\circ} \mathrm{C}$, the O.D.600 $\mathrm{nm}$ was measured.

\subsection{In Vivo Analysis}

2.7.1. Gene Expression of Cytokines in Mice Ileum

The experiments were conducted on male BALB/c mice (weight $25-30 \mathrm{~g}$, six weeks old) obtained from Centro de Bioterismo (CEBIO) of the Institute of Biological Sciences at the Federal University of Minas Gerais (UFMG). The animals were kept in polycarbonateventilated cages under controlled conditions: temperature around $21 \pm 2{ }^{\circ} \mathrm{C}$ with a 12 -h light/dark cycle, and ad libitum access to water and standard chow diet $24 \mathrm{~h}$ before experiments. All procedures followed the Brazilian College of Animal Experimentation (COBEA), and the Local Animal Experimental Ethics Committee (CEUA-UFMG) approved the project (Protocol n 112/2020). 


\subsubsection{CIDCA 133 Administration}

Mice were randomized into two experimental groups ( $n=6$ animals per group): INC (negative control) and II- CIDCA 133. These groups were administered by continuous feeding with $100 \mathrm{~mL} /$ cage of MRS broth (CTL group) or CIDCA $133\left(5 \times 10^{7} \mathrm{CFU} / \mathrm{mL}\right)$ for 13 consecutive days. After the experimentation period, the animals were euthanized by a single intraperitoneal injection of anesthetic overdose $(30 \mathrm{mg} / \mathrm{kg}$ of xylazine and $300 \mathrm{mg} / \mathrm{kg}$ of ketamine mixture) (Ceva, São Paulo, Brazil) and samples of the intestine (ileum section) were collected and stored in RNAlater ${ }^{\circledR}$ solution (Invitrogen, Carlsbad, CA, USA).

\subsubsection{RNA Extraction and Quantitative Polymerase Chain Reaction (qPCR)}

According to the manufacturer's instructions, the total RNA of ileum sections ( 20 mg) was obtained using the RNeasy Mini Kit (QIAGEN, Hilden, Germany). The RNA quality and concentration were evaluated on $1.5 \%$ agarose gel electrophoresis and through the NanoDrop ${ }^{\circledR} 2000$ spectrophotometer (Thermo Scientific, Waltham, MA, USA), respectively. Residual DNA was digested with DNAse I from the TURBO DNA-free ${ }^{\mathrm{TM}}$ Kit (Invitrogen, Carlsbad, CA, USA), following the manufacturer's instructions. The complementary deoxyribonucleic acid (cDNA) synthesis was produced with the Applied Biosystems ${ }^{\mathrm{TM}}$ High-Capacity cDNA Reverse Transcription kit (ThermoFisher, Waltham, MA, USA), according to the manufacturer's instructions.

Quantitative PCR (qPCR) was performed using the PowerUp ${ }^{\mathrm{TM}}$ SYBR ${ }^{\circledR}$ Green Master Mix (ThermoFisher, Waltham, MA, USA) and the genes-specific primers for Tlr2, Tlr4, Myd88, Nfkb1, Tnf, Il1b, Il6, Il12, Il10, Il17a, Tgfb1, and Muc2 (Table 2). Amplification reactions were performed on the Applied Biosystems 7900HT Fast Real-Time PCR System under the following conditions: initial denaturation at $95^{\circ} \mathrm{C}$ for $10 \mathrm{~min}, 95^{\circ} \mathrm{C}$ for $15 \mathrm{seg}$, annealing/extension at $60^{\circ} \mathrm{C}$ for $1 \mathrm{~min}, 40$ cycles followed by a dissociation stage for recording the melting curve. The expression of target genes was analyzed by the $2^{-\Delta \Delta C t}$ method using housekeeping genes encoding $\beta$-actin (actb) and GAPDH (gapdh) as endogenous references.

Table 2. Quantitative Polymerase Chain Reaction (qPCR) primers used in this study.

\begin{tabular}{ccccc}
\hline Gene & Primer Forward & Primer Reverse & $\begin{array}{c}\text { Amplicon } \\
\text { Size } \mathbf{b p})\end{array}$ & Reference \\
\hline Actb & GCTGAGAGGGAAATCGTGCGTG & CCAGGGAGGAAGAGGATGCGG & 100 & {$[58]$} \\
\hline Gapdh & TCACCACCATGGAGAAGGC & GCTAAGCAGTTGGTGGTGCA & 168 & {$[59]$} \\
\hline$I l 6$ & GAGGATACCACTCCCAACAGACC & AAGTGCATCATCGTTGTTCATACA & 141 & {$[59]$} \\
\hline$I l 10$ & GGTTGCCAAGCCTTATCGGA & ACCTGCTCCACTGCCTTGCT & 191 & {$[59]$} \\
\hline$I l 12 p 40$ & GGAAGCACGGCAGCAGAATA & AACTTGAGGGAGAAGTAGGAATGG & 180 & {$[59]$} \\
\hline$T n f$ & ACGTGGAACTGGCAGAAGAG & CTCCTCCACTTGGTGGTTTG & 236 & {$[60]$} \\
\hline$I l 1 b$ & CTCCATGAGCTTTGTACAAGG & TGCTGATGTACCAGTTGGGG & 245 & {$[60]$} \\
\hline$I l 17 a$ & GCTCCAGAAGGCCCTCAGA & AGCTTTCCCTCCGCATTGA & 142 & {$[59]$} \\
\hline$T g f b 1$ & TGACGTCACTGGAGTTGTACGG & GGTTCATGTCATGGATGGTGC & 170 & {$[59]$} \\
\hline$M u c 2$ & GATGGCACCTACCTCGTTGT & GTCCTGGCACTTGTTGGAAT & 246 & {$[58]$} \\
\hline$M y d 88$ & ATCGCTGTTCTTGAACCCTCG & CTCACGGTCTAACAAGGCCAG & 199 & {$[61]$} \\
\hline$T l r 2$ & ACAATAGAGGGAGACGCCTTT & AGTGTCTGGTAAGGATTTCCCAT & 149 & {$[61]$} \\
\hline$T l r 4$ & ATGGCATGGCTTACACCACC & GAGGCCATTTTTGTCTCCACA & 129 & {$[61]$} \\
\hline$N f k b 1$ (p105) & GTGGAGGCATGTTCGGTAGTG & TCTTGGCACAATCTTTAGGGC & 195 & {$[62]$} \\
\hline
\end{tabular}




\subsection{Statistical Analysis}

The experiments were done in triplicate (gastric juice, osmotic and thermal stress tolerance, bacterial antagonism) or duplicate (qPCR analysis). The results were presented as mean and standard deviation (SD). Statistical differences between the two groups were performed by the Student's $t$-test (thermal stress tolerance, qPCR, and bacterial antagonism analysis). Stress experiments (gastric juice and osmotic stress tolerance) were performed by analyzing variance (ANOVA) followed by Tukey's post hoc test. All data were analyzed using the GraphPad Prism 8.0 software, and a $p$-value $<0.05$ was considered significant.

\section{Results}

\subsection{L. delbrueckii CIDCA 133 General Genomic Features}

Genome sequencing of $L$. delbrueckii CIDCA 133 strain revealed a single circular chromosomal DNA of 2,127,785 bp, with a GC\% content of 49.57\%, 27 rRNA, 98 tRNA, 153 pseudogenes, 2132 genes, and a total of 2004 protein-coding sequences (CDS). Additionally, the presence of one plasmid sequence was detected in CIDCA 133 (Figure 1). This plasmid had $6224 \mathrm{bp}$, a GC content of $44.67 \%$, and six CDSs.

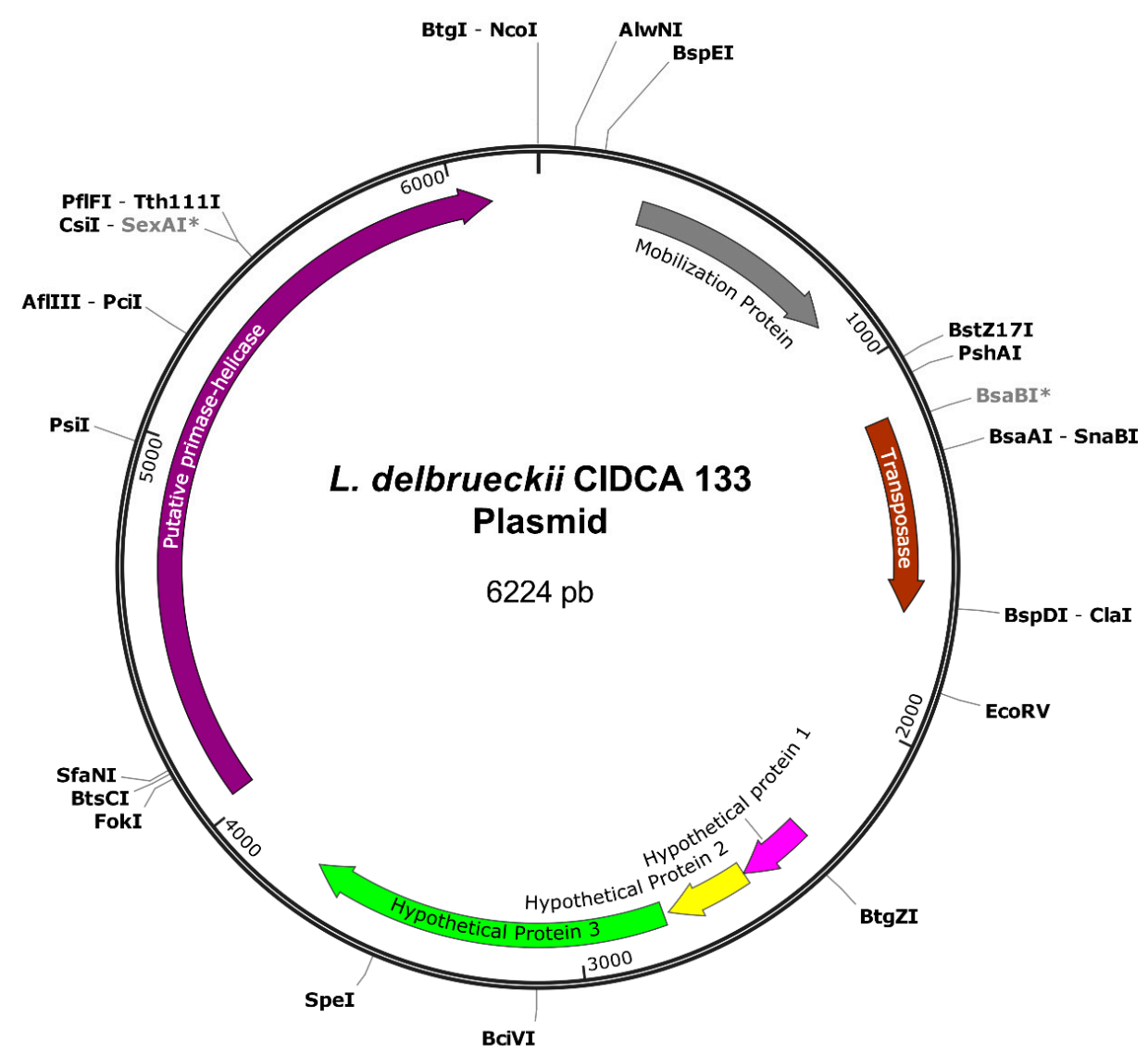

Figure 1. Schematic representation of the plasmid circular map present in Lactobacillus delbrueckii CIDCA 133 and restriction enzyme cut sites. Asterisk (*) indicates site blocked by methylation.

\subsection{Gene Ontology (GO) Annotation}

A total of 1590 genes of CIDCA 133 exhibited results in the GO FEAT platform's functional annotation. The GO terms were represented in three categories: molecular function $(50.94 \%$ hits), biological process $(27.06 \%$ hits), and cell component ( $22 \%$ hits) (Figure 2A).

The cellular component category contained GO terminologies involved in membrane function (integral components of the membrane, plasm membrane) and cytoplasmic function (ribosome), among others (Figure 2B). For molecular function, it was identified that 
the main GO terminologies functions referred to protein binding (DNA, ATP, and metalbinding) and catalytic activity (ATPase and hydrolase activity), among others (Figure 2C).

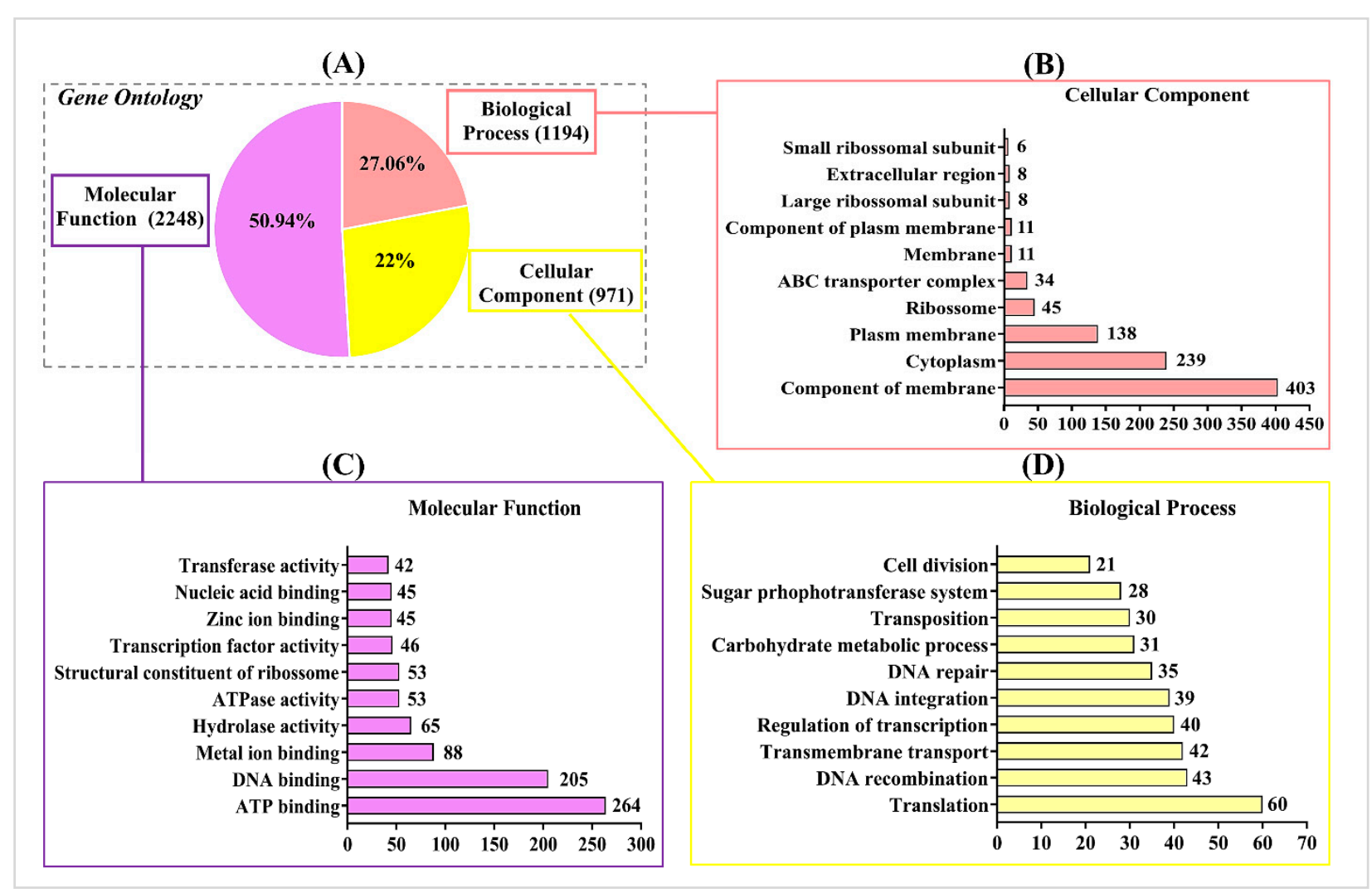

Figure 2. Distribution of Lactobacillus delbrueckii subsp. lactis CIDCA 133 (CIDCA 133) genes among the Gene Ontology (GO) categories predicted in Gene Ontology Functional Enrichment Annotation Tool (GO FEAT) (A). The genes were distributed in Cellular component (B), Molecular function (C), and Biological process (D) categories.

For the biological process category, the most representative GO terms were translation, transmembrane transport, DNA repair, and carbohydrate metabolism (Figure 2D).

\subsection{Species Identification}

The CIDCA 133 identification by MALDI-TOF Biotyper ${ }^{\circledR}$ classified this strain as belonging to the L. delbrueckii species, but with a certain degree of uncertainty (score <2.2). However, pairwise comparisons of the Average Nucleotide Identity based on BLAST (ANIb) indicate that CIDCA 133 genome presented an identity threshold $>97 \%$ with 26 L. delbrueckii genomes (Figure 3), consistent with their identification as members of the same species.

ANIb distance between the strains indicated the formation of two main clades: one represented by strains of L. delbrueckii subsp. delbrueckii, L. delbrueckii subsp. jakobsenii and L. delbrueckii subsp. lactis (red region upper right), and the other included strains of L. delbrueckii subsp. bulgaricus (red region, lower left). This phylogenomic analysis shows that $L$. delbrueckii CIDCA 133 is closely related to the clade of the L. delbrueckii subsp. lactis species $(\mathrm{ANIb}>98 \%)$.

\subsection{CIDCA 133 Tolerates Acid, Osmotic and Thermal Stresses}

Genes coding for proteins involved in acid, thermal, osmotic and bile salt resistance were identified in CIDCA 133 genome. These genes encode proteins as ornithine decarboxylase, F0F1-ATP synthase (acid stress), $\mathrm{Na}(+) / \mathrm{H}(+)$ antiporter $\mathrm{NhaC}$, aquaporin family 
protein (osmotic stress), choloylglycine hydrolase, S-ribosylhomocysteine lyase (bile salt stress), chaperones (GroEL, DnaK) (heat stress), among others (Table 3).

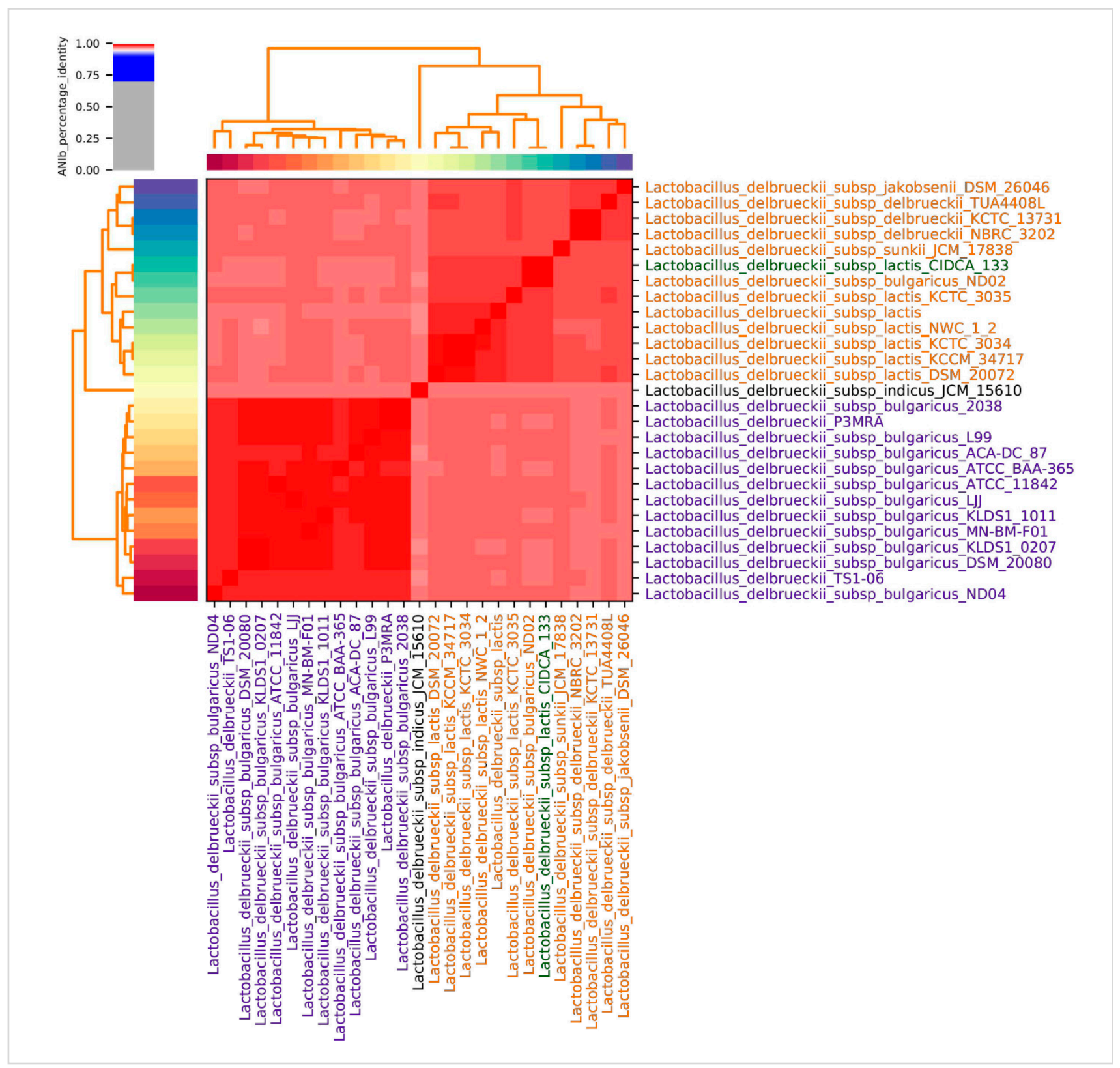

Figure 3. Heatmap representing the degree of similarity between Lactobacillus delbrueckii genomes based on the Average Nucleotide Identity (ANI). Red = more similar, light red = less similar.

Additionally, the capacity of CIDCA 133 to tolerate these stressors agents was evaluated. For acid stress, it was observed that compared to the initial time $(0 \mathrm{~h})$, the viability of CIDCA 133 decreased after $2 \mathrm{~h}$ and $4 \mathrm{~h}$ in contact with artificial gastric juice, but the strain continued to maintain a high survival rate: $77.7 \%(2 \mathrm{~h})$ and $67.4 \%(4 \mathrm{~h})$, thus being able to grow after acid $\mathrm{pH}$ challenge (Figure $4 \mathrm{~A}$ ).

For osmotic stress, no change in the growth of CIDCA 133 was observed in the presence of $1 \%, 2 \%$, and $3 \% \mathrm{NaCl}$. The strain showed a growth rate of $99.5 \%, 98.1 \%$, and $87.6 \%$, respectively. These results are like bacteria that were not submitted to osmotic stress $(\mathrm{NaCl} 0 \% ; 100 \%$ in the growth rate). However, when the $\mathrm{NaCl}$ concentration was increased 
to $4 \%$ and $5 \%$, the strain had a growth rate of $48.1 \%$ and $31.7 \%$, respectively, revealing that these high concentrations of $\mathrm{NaCl}$ reduce the CIDCA 133 growth (Figure 4B).

Table 3. Gene's prediction involved with stress tolerance of Lactobacillus delbrueckii CIDCA 133.

\begin{tabular}{|c|c|c|c|}
\hline Locus Tag & Gene & Protein & Stress Condition \\
\hline HR078_02445 & Odcl & Ornithine decarboxylase & Acid \\
\hline HR078_03205 & $a t p D$ & F0F1-ATP synthase subunit beta & Acid \\
\hline HR078_03195 & $\operatorname{atp} A$ & F0F1- ATP synthase subunit alpha & Acid \\
\hline HR078_03180 & $\operatorname{atpE}$ & F0F1-ATP synthase subunit C & Acid \\
\hline HR078_03185 & $\operatorname{atpF}$ & F0F1-ATP synthase subunit B & Acid \\
\hline HR078_03210 & $\operatorname{atpC}$ & F0F1-ATP synthase epsilon & Acid \\
\hline HR078_03190 & $\operatorname{atpH}$ & F0F1-ATP synthase delta & Acid \\
\hline HR078_03200 & $\operatorname{atp} G$ & F0F1-ATP synthase gamma & Acid \\
\hline HR078_03175 & $\operatorname{atpB}$ & F0F1-ATP synthase subunit A & Acid \\
\hline HR078_03560 & $\operatorname{clpX}$ & ATP-dependent ClpX protease & Acid \\
\hline HR078_00335 & ark & Aldo/keto reductase & Osmotic \\
\hline HR078_09455 & $g l p F$ & Aquaporin family protein & Osmotic \\
\hline HR078_10525 & $\operatorname{nag} B$ & Glucosamine-6-phosphate deaminase & Biliar \\
\hline HR078_01470 & pyrG & CTP synthase & Biliar \\
\hline HR078_09705 & pepF & Oligoendopeptidase F & Biliar \\
\hline HR078_04350 & cbh & Choloylglycine hydrolase family protein & Biliar \\
\hline HR078_07785 & groel & chaperonin GroEL & Heat \\
\hline HR078_06405 & hor $A$ & Heat-inducible transcription repressor HrcA & Heat \\
\hline HR078_06390 & $d n a J$ & Molecular chaperone DnaJ & Acid, Biliar, Osmotic, Heat \\
\hline HR078_06395 & dnaK & Molecular chaperone DnaK & Acid, Biliar, Osmotic, Heat \\
\hline HR078_06400 & $g r p E$ & Nucleotide exchange factor GrpE & Acid, Biliar, Osmotic, Heat \\
\hline HR078_00560 & YyclC & Two-component system regulatory protein & Acid, Biliar, Osmotic, Heat \\
\hline HR078_08640 & nhaC & $\mathrm{Na}+/ \mathrm{H}+$ antiporter $\mathrm{NhaC}$ & Acid, Osmotic \\
\hline HR078_06090 & $c l p P$ & Clp protease ClpP & Acid, Biliar \\
\hline HR078_06270 & $\operatorname{clp} E$ & AAA family ATPase & Acid, Biliar \\
\hline HR078_06320 & eno & Phosphopyruvate hydratase & Acid, Biliar \\
\hline HR078_00380 & $\operatorname{luXs}$ & S-ribosylhomocysteine lyase & Osmotic, Biliar \\
\hline
\end{tabular}

(A)

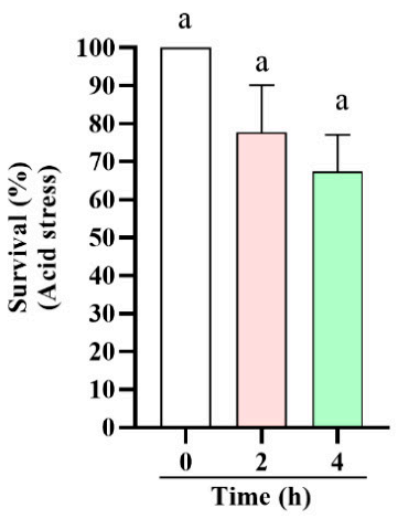

(B)

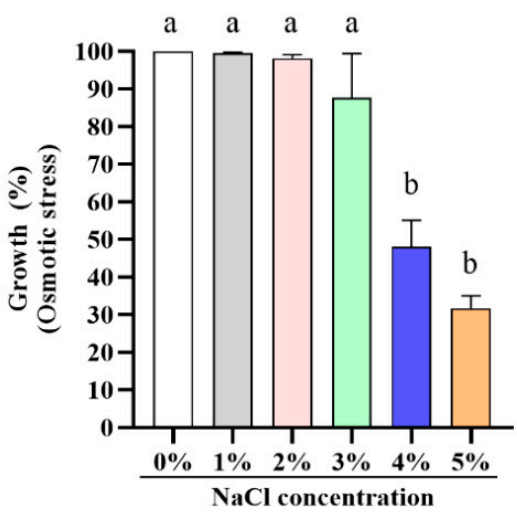

(C)

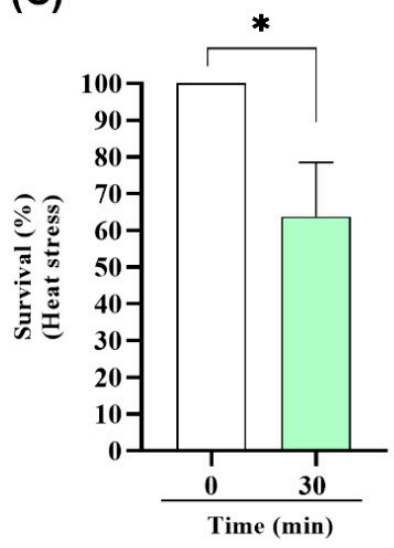

Figure 4. L. delbrueckii CIDCA 133 tolerates different stressors. (A) Survival percentage in acid stress (0.3\% pepsin solution $\mathrm{pH}$ 3.0). (B) The growth rate in different concentrations of $\mathrm{NaCl}(1-5 \%)$. (C) Survival percentage in heat stress. Different letters and * indicate statistically significant differences $(p<0.05)$ by ANOVA followed by Tukey's post hoc test (acid and osmotic stress) and Student's $t$-test (thermal stress).

After heat stress, it was observed that CIDCA 133 presented $63.75 \%$ of viability, revealing that the strain can tolerate high temperature (Figure $4 \mathrm{C}$ ). 


\subsection{Proteolytic System, Symbiotic, and Metabolic Genomic Islands}

Based on data from the literature, through manual inspection of the CIDCA 133 genome annotation, it was possible to identify CDS possibly related to the strain proteolytic activity. CIDCA 133 genome encodes genes related to cell-wall bound proteinase ( $\operatorname{Pr} B$, PrtM), different classes of peptidases (pepN, pepC, pepV, pepT, pepO, pepX), and peptide transporters (oppA, oppC, dppB, dppE) (Table S2).

Additionally, twelve genomic islands (GEIs) were identified: seven symbiotic (SI) and five metabolic islands (MI), respectively (Figure 5). All CDS of CIDCA 133 GEIs are described in Table S3.

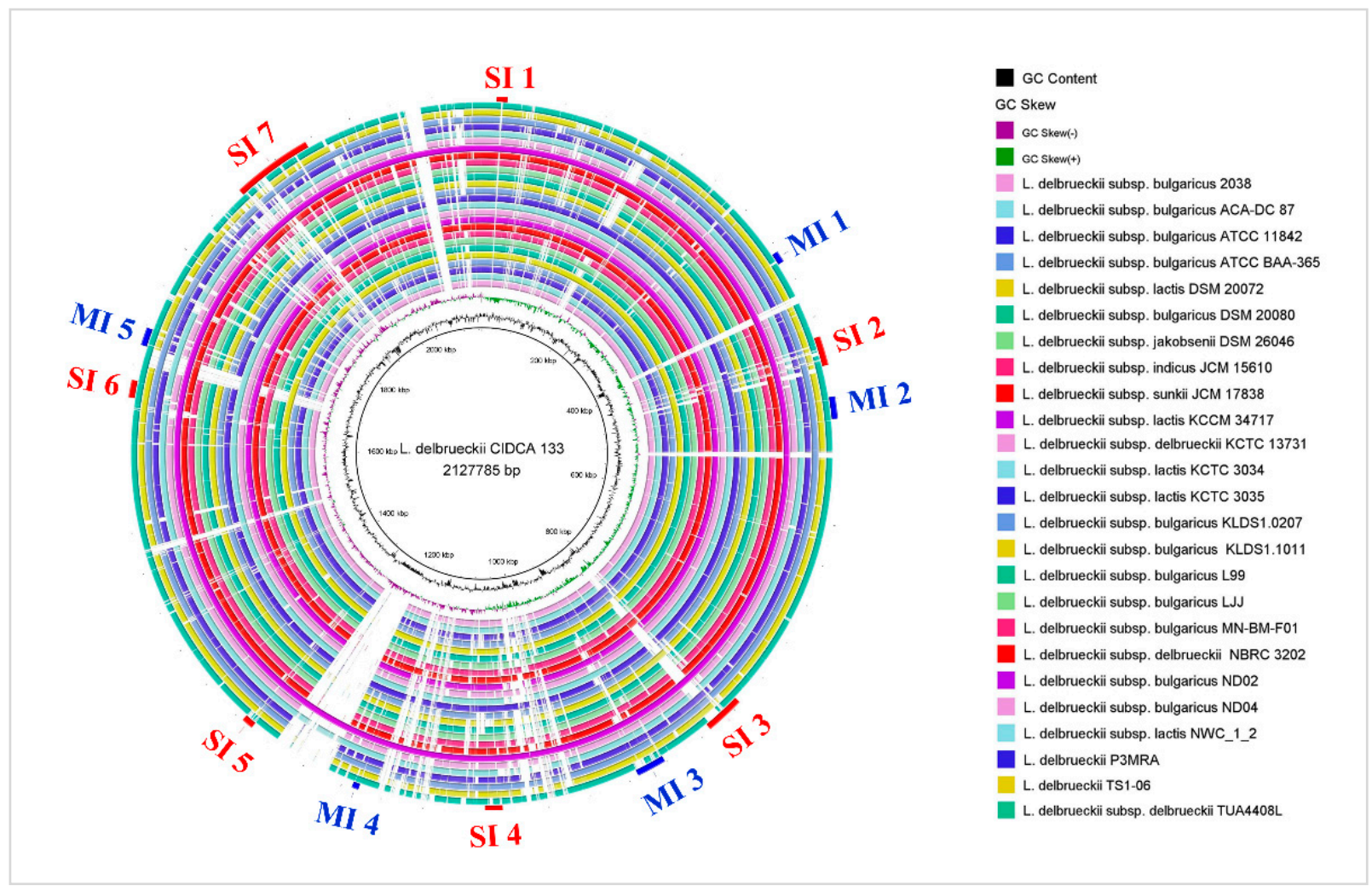

Figure 5. Circular schematic representation of Metabolic (MI) and Symbiotic (SI) islands predicted with GIPSy software in CIDCA 133 genome and its comparison with others L. delbrueckii complete genomes. Each ring of the circle corresponds to a specific $L$. delbrueckii whole genome, represented by different colors in the legend (right).

\subsection{Putative Bacteriocins and Antibacterial Activity}

In CIDCA 133 genome, the BAGEL4 web server predicted three bacteriocins belonging to class III: two helveticin-J (Figure 6A,C) (330 and 331 amino acids, respectively) and enterolysin-A (Figure 6B) (269 amino acids).

Additionally, to determine whether L. delbrueckii CIDCA 133 exhibited antibacterial activity, a bacterial inhibition assay was performed based on inhibitory compounds present in its culture supernatant. The bacterial culture supernatant (CFS) had an approximate $\mathrm{pH}$ of 3.8 after $24 \mathrm{~h}$ of growth and was able to inhibit the growth of pathogens, such as L. monocytogenes $(90.9 \% \pm 1.70)$, E. faecalis $(88.4 \% \pm 7.5)$, S. sonnei $(91.6 \% \pm 2.6)$, and S. enterica Typhimurium $(84 \% \pm 11.1)$. In addition, the CIDCA 133 supernatant effect was evaluated in other Lactobacillus species, such as L. delbrueckii CNRZ327 and L. paracasei BL23, in which it was possible to observe an inhibition rate against these bacteria of $77.7 \% \pm 4.9$ and $88.8 \% \pm 0.14$, respectively (Figure $6 \mathrm{D}$ ). After the neutralization of supernatant (nCFS) $(\mathrm{pH}=6.5)$, it was possible to observe a reduction in the inhibition rate of L. monocytogenes $(35.9 \% \pm 1.12 ; p=0.0007)$, E. faecalis $(30.95 \% \pm 0.3 ; p=0.0086)$, S. sonnei 
$(39.7 \% \pm 6.6 ; p=0.0094)$, S. enterica Typhimurium $(34.71 \% \pm 3.3 ; p=0.0267)$, L. paracasei BL23 $(29.4 \% \pm 4.1 ; p=0.0024)$, and L. delbrueckii CNRZ327 $(42.41 \% \pm 8.7 ; p<0.05)$ (Figure 6D).

(A) Helveticin-J

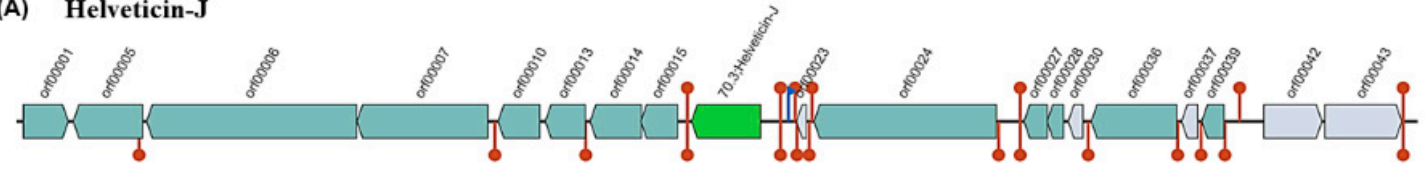

(B) Enterolysin-A

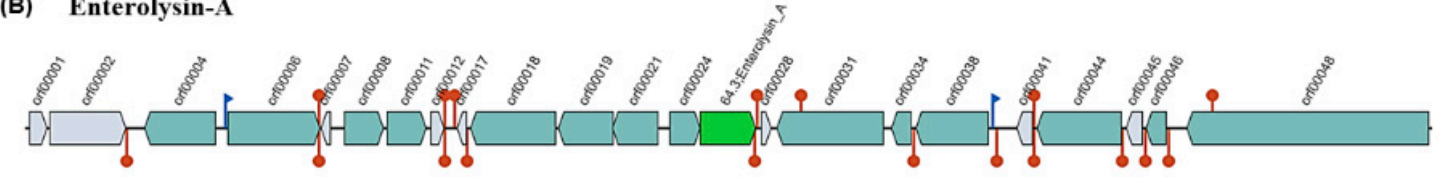

(C) Helveticin-J

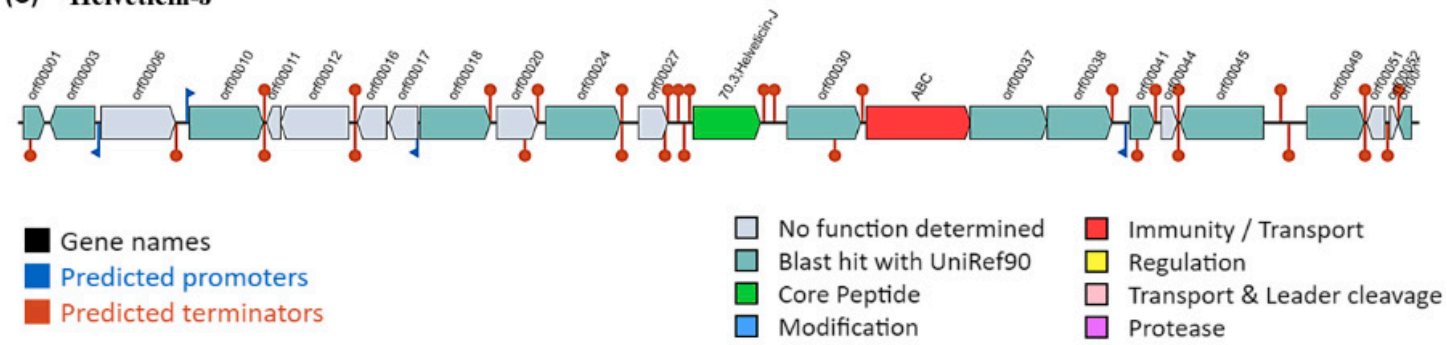

(D)

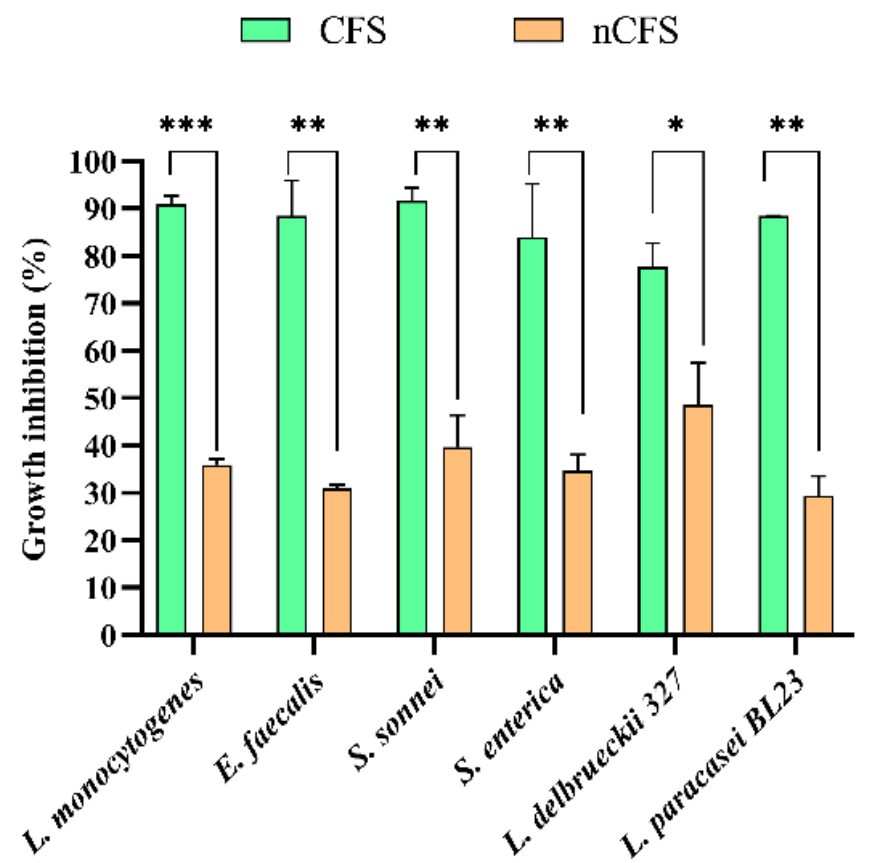

Figure 6. Schematic representation of bacteriocin gene operon (A-C) present in L. delbrueckii CIDCA 133 genome predicted by BAGEL4. (D) Antibacterial activity spectrum of bacterial supernatants from L. delbrueckii CIDCA 133 against pathogenic and non-pathogenic bacteria. Asterisk indicates statistical difference by Student's $t$-test: ${ }^{*} p<0.05,{ }^{* *} p<0.01,{ }^{* * *} p<0.001$. 


\subsection{Cell Adhesion-Related Genes}

Using SurfG+ software, it was found that 1606 proteins of CIDCA 133 are cytoplasmic (CYT), 312 membrane (ME), 156 protein surfaces exposed (PSE), and 58 secreted (SE) (Figure 7A; Table S4). According to the Vaxign web server, 16 of the predicted proteins sub located on the membrane, 48 PSE and 38 secreted had high cell adhesion probability (Figure 7B; Table S5). These proteins-encoding genes include the SLAP domain-containing protein $(S L A P)$, peptidase $S 8(P r t B)$, MucBP domain protein $(M u c B)$, aggregation promoting factor $(A p f)$, lipoteichoic acid synthase family protein $(L t a S)$, trypsin-like serine protease $(H \operatorname{tr} A)$, among others.

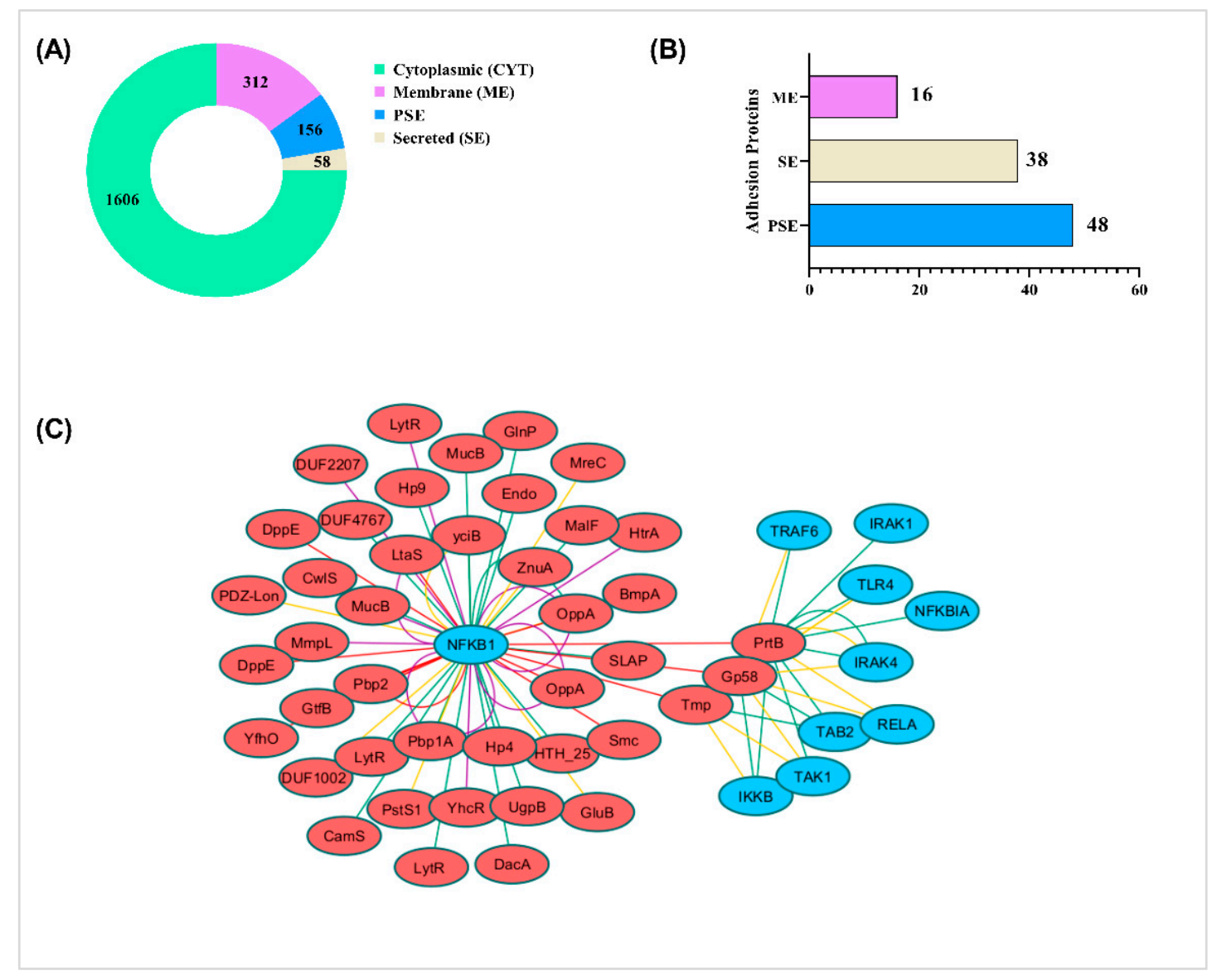

Figure 7. Distribution of subcellular localization of CIDCA 133 proteins predicted by SurfG+ software (A). Several proteins with high probably adhesion capacity predicted by Vaxign software (B). Protein-protein interaction network mapping to the KEGG toll-like receptor/nuclear factor каpра B (TLR/NF- $\mathrm{BB}$ ) signaling pathway. Red circle nodes represent bacteria proteins, and blue circle nodes represent human proteins. The strongest associations are represented with different colors line. Interaction score: 0.97 (yellow line), 0.98 (green line), 0.99 (purple line), 1.0 (red line) (C).

\subsection{Protein-Protein Interaction}

The CIDCA 133 and human protein-protein interaction by InterSPPI predicted 74 interactions (Table S6). The nuclear factor NF- $\kappa$ B p105 subunit (NFKB1) was the most frequent interacting human protein. On the other hand, the PrtB protein (a cell surface proteinase) was the most frequent interacting CIDCA 133 protein. CIDCA 133 proteins also interacted with other human proteins involved with the TLR/NF- $\mathrm{KB}$ signaling pathway activation, such as TLR4, IRAK4, IRAK1, TRAF6, TAB2, TAK1, IKKB, RELA, and NFKBIA (Figure 7C). 


\subsection{CIDCA 133 Influences on Intestinal Mucosa Immune System}

Consumption of CIDCA 133 was also reported to modulate ileal expression of cytokines genes in mice. After oral CIDCA 133 administration, it was possible to observe a downregulation in the mRNA expression of inflammatory cytokines $\operatorname{Tnf}(0.79 \pm 0.12)$, Il6 $(0.67 \pm 0.11), I l 12(0.42 \pm 0.16), \operatorname{Il} 1 b(0.56 \pm 0.14)$, and Il17a $(0.31 \pm 0.25)$ when compared to those exhibited in the NC group: $\operatorname{Tnf}(1.00 \pm 0.18 ; p=0.0406), \operatorname{Il6}(1.00 \pm 0.20 ; p=0.0064)$, Il12 (1.00 $\pm 0.19 ; p=0.0004), \operatorname{Illb}(1.00 \pm 0.18 ; p=0.0011)$, and Il17a $(1.00 \pm 0.30 ; p=0.0017)$ (Figure 8).

(A)

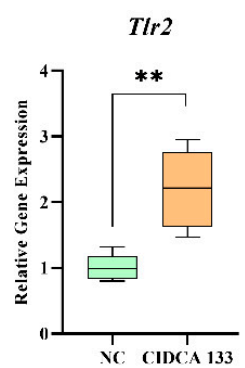

(E)

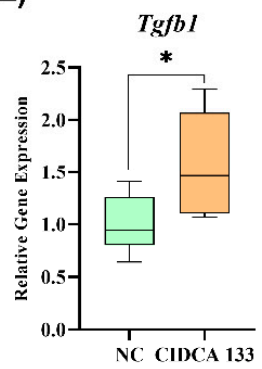

(l)

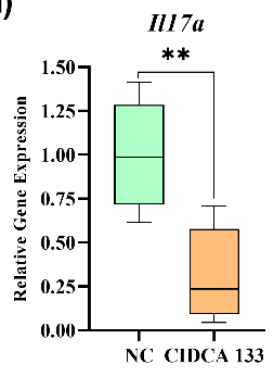

(B)

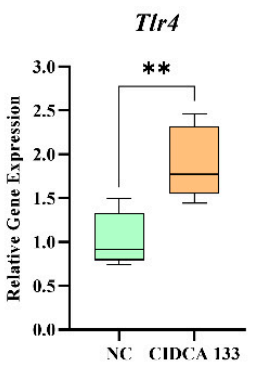

(F)

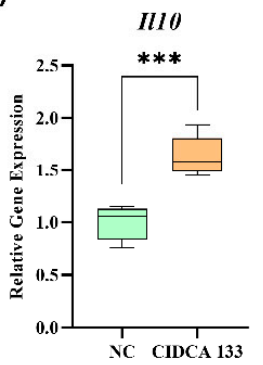

(J)

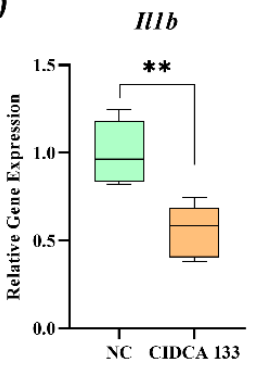

(C)

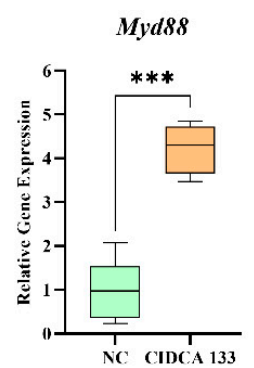

(G)

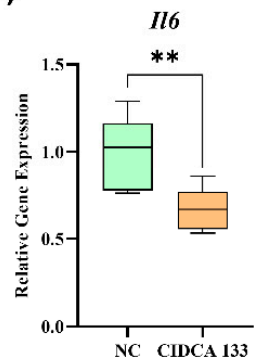

(K)

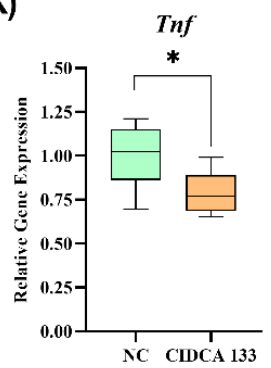

(D)

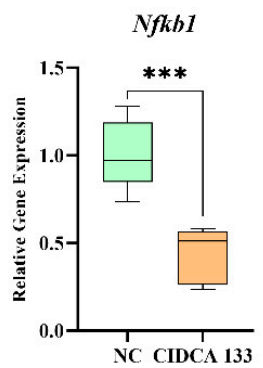

(H)

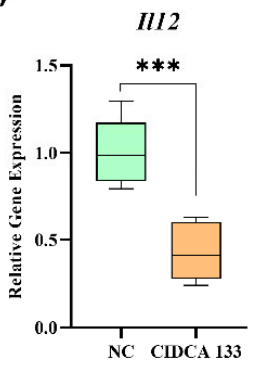

(L)

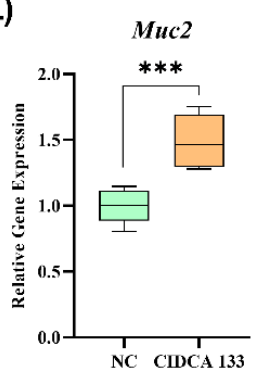

Figure 8. Relative gene expression of (A-L) Tlr2, Tlr4, Myd88, Nfkb1, Tgfb1, Il10, Il6, Il12, Il17a, Il1b, Tnf, and Muc2 in the ileum section of animals that received oral administration of L. delbrueckii CIDCA 133 for 13 consecutive days. Asterisk indicates statistical difference by Student's $t$-test: ${ }^{*} p<0.05,{ }^{* *} p<0.01,{ }^{* * *} p<0.001$.

On the other hand, the mRNA expression of Muc2 (1.48 \pm 0.19$), \operatorname{Tl} 2(2.19 \pm 0.59)$, Tlr4 (1.90 \pm 0.41$), \operatorname{Myd} 88$ (4.22 \pm 0.57$), N f k b 1$ (0.44 \pm 0.15$), T g f b 1$ (1.56 \pm 0.48$)$, and Il10 $(1.63 \pm 0.18)$ were upregulated after oral administration of CIDCA 133 in relation to the NC group: Muc2 (1.00 $\pm 0.12 ; p=0.0010), \operatorname{Tl} 2(1.00 \pm 0.20 ; p=0.0028), \operatorname{Tl} 4(1.00 \pm 0.30$; $p=0.0052)$, Myd88 (1.00 $\pm 0.67 ; p<0.0001), N f k b 1(1.00 \pm 0.19 ; p=0.0003), T g f b 1(1.00 \pm 0.27 ;$ $p=0.0325)$, and Il10 (1.00 $\pm 0.15 ; p=0.0002)$ (Figure 8). 


\section{Discussion}

Lactobacillus strains have functional characteristics beneficial to the host, such as an anti-inflammatory effect and resistance and adaptation mechanisms to the GIT conditions. These features lead these microorganisms to have high relevance in the biotechnological and industrial food sector $[5,63]$ for their use as a probiotic supplement. Due to these properties, specific mechanisms of action of these microorganisms have been elucidated through omics investigations [18].

L. delbrueckii CIDCA 133 has emerged as a potential probiotic strain [10,22,25]. Based on its beneficial effects, species identification, gene product function, and potential molecular mechanisms associated with these strain's probiotic effects were investigated in this work through a genome and phenotype-scale analysis.

CIDCA 133 had its identification performed by classical microbiological methods. Both MALDI-TOF Biotyper ${ }^{\circledR}$ and Average Nucleotide Identity (ANI) analysis supported this classification, which showed that this strain presents a high similarity with the others belonging to the L. delbrueckii subsp. lactis species [64]. The CIDCA 133 genome had about $2.2 \mathrm{Mb}$ and 2004 protein-coding sequences. In addition, this strain had one plasmid sequence (6224 bp). According to Lee et al. [65], the presence of plasmids in L. delbrueckii strains is rare, unlike other Lactic Acid Bacteria (LAB) species. The low number of plasmid sequences of this species deposited in the NCBI corroborates this fact, with only four plasmid sequences deposited (Access Number: CP002342.1; CP018612.1; CP018613.1 and CP029251.1).

Probiotic microorganisms must resist stress in both product matrices and during their passage through the GIT to produce many beneficial effects on the host's health. CIDCA 133 harbored many genes encoded for stress-related proteins, such as a two-component system sensor, F0F1 ATP synthase, ornithine decarboxylase, phosphopyruvate hydratase, and choloylglycine hydrolase. These proteins respond to specific stress stimulus and generate a broad range of response results [45]. Furthermore, these genetic factors can be associated with CIDCA 133 survival capacity to simulated gastric juice reported in this study and to the data found by Kociubinski et al. [23], which demonstrated for the first time the ability of CIDCA 133 to resist bile salt $(0.1 \%$ and $0.5 \%)$. These genes were also previously shown to be involved with the capacity of L. rhamnosus [66], Limosilactobacillus reuteri (L. reuteri) [67], and L. helveticus [47] strain to survive to $\mathrm{pH} 3$ and $0.3 \%$ bile salt for $2-3 \mathrm{~h}$.

CIDCA 133 also carried genes, such as $\mathrm{Na}+/ \mathrm{H}+$ antiporter (NhaC), S-ribosylhomocysteine lyase $(l u X s)$, aquaporin family protein $(g l p F)$, and heat shock proteins (DnaK, DnaJ, GroEL), which may be related to its ability to tolerate different concentrations $(1 \%-3 \%)$ of sodium chloride (osmotic stress) and heat stress, respectively. These findings corroborate with other studies that demonstrated that different Lactobacillus species could tolerate different $\mathrm{NaCl}$ concentrations, such as Lactiplantibacillus plantarum (L. plantarum) [68] that tolerates up to $5 \%$ of $\mathrm{NaCl}$, L. paracasei [56] and L. delbrueckii subsp. bulgaricus [69], which tolerated up to $4 \% \mathrm{NaCl}$.

Sodium chloride is generally used in the fermented food industry, such as cheese [70]. However, varying concentrations of sodium chloride present in these products and the high temperature used for their production can compromise probiotic bacteria's viability and activity [71,72]. Therefore, the ability of CIDCA 133 to resist acid, bile, different concentrations of $\mathrm{NaCl}(1-3 \%)$, and pasteurization temperature allows this strain to perform better at its health-promoting site of action and makes it promising for application in the food sector for the development of dairy fermented products with functional characteristics.

When consumed, probiotic bacteria must also have the ability to interact with intestinal epithelial cells, which is a crucial factor for their interaction activation with the host [73,74]. Several studies have demonstrated the involvement of extracellular and surface-bound proteins identified in the bacteria/host interaction, leading to biological processes, such as cell adhesion, competitive exclusion of pathogens, and mucosal immune regulation. These proteins include SlpB, slpE, htrA4, and hsdM3 of P. freudenreichii CIRM-BIA 129 
and CIRM-BIA 121 [75-77], and SlpA of L. acidophilus [78] and L. helveticus MIMLh5 [79], among others.

In the CIDCA 133 genome, 312 membrane proteins, 58 secreted and 156 surfaces exposed (PSE) were predicted. Of these, 102 were identified with a high probability of cell adhesion, such as the SLAP domain-containing protein, MucBP domain-containing protein, lipoteichoic acid synthase family protein, proteinase $\mathrm{PrtB}$, and aggregation promoting factor. These proteins can be involved in the protective effects of CIDCA 133 against Bacillus cereus [25] and Citrobacter rodentium [26] infection. This bacteria stimulated immune cell responses (macrophages and dendritic cells derived from human monocytes) infected with these pathogens to reduce the infection by producing co-stimulatory and effector molecules (TNF- $\alpha$, IL-6, IL-8, and iNOS).

Lactobacillus strains can modulate the host's immune response through their interaction with intestinal epithelial cells [80] mainly conducted by toll-like receptors (TLRs), which when activated can stimulate the activation of signaling pathways, such as the nuclear factor кappa B (NF-kB) and mitogen-activated protein kinase (MAPK), with subsequent production of cytokines [81].

The immunostimulatory capacity of CIDCA 133 in vivo was evaluated in this work. It was possible to observe an increase in the gene expression of Tlr2, Tlr4 and Myd88 after CIDCA 133 strain consumption. These findings are supported by other studies, which observed that administration of the probiotics Lacticaseibacillus casei (L. casei) and Saccharomyces boulardii could also stimulate the mucosal immune system of healthy mice and broilers, respectively, by increasing gene expression of Tlr2, Tlr4, and Myd88 [82,83].

The NF- $\kappa B$ pathway leads to the upregulation of pro-inflammatory genes that, if not controlled at homeostatic levels, can lead to the onset and progression of inflammatory bowel diseases (IBDs) [84-86]. Several probiotics can downregulate the expression of proinflammatory cytokines. L. acidophilus was able to decrease the intestinal damage caused by 5 -Fluorouracil (5-FU) $(450 \mathrm{mg} / \mathrm{kg})$ by inhibiting the signaling of the NF- $\mathrm{kB}$ pathway and observing low levels of pro-inflammatory cytokines TNF- $\alpha$ and IL-1 $\beta$ [87]. L. gasseri $4 \mathrm{M} 13$ inhibited the release of inflammatory mediators, such as TNF- $\alpha$, IL- 6 , IL-1 $\beta$, and induced IL-10, in LPS-stimulated RAW 264.7 macrophages [88]. In addition, L. helveticus SBT2171 induces A20 gene expression for inhibiting the activation of NF- $\mathrm{KB} / \mathrm{MAPKs}$ and IL-6 and IL-1 $\beta$ production in macrophages cell [89].

Knowing the reduction in pro-inflammatory cytokines expression is also reported as a positive effect of probiotic microorganisms [82,83], in this work, a reduction in proinflammatory (Tnf, Il6, Il12, Il17a, and Il1b) and an increase in anti-inflammatory (Tgfb1 and Il10) cytokines gene expression in health mice was observed after oral CIDCA 133 administration. This modulation can be related to the downregulation of $N f k b 1$ gene expression. This result is following the InterSPPI prediction since the nuclear factor NF- $\mathrm{kB}$ p105 subunit (NFKB1) was the most frequent interacting human protein with CIDCA 133 proteins, suggesting these proteins are possibly involved with its immunomodulatory property. However, other studies must be performed to validate this finding, such as CIDCA 133 knockout genes or heterologous production of these proteins, and their phenotypic evaluation on inflammation models.

Some studies have also demonstrated that epithelial activation of TLR2/TLR4 is associated with the development and maturation of mucus-producing goblet cells [90,91]. This finding supports the results reported in this work, in which it was observed that oral administration of CIDCA 133 also increased the gene expression of the MUC2 protein (mucin 2), one of the main components of the intestinal mucus layer.

Based on these findings, it can also be inferred that the modulation of the epithelial barrier markers and immune system to an anti-inflammatory profile by CIDCA 133 in healthy mice can be associated with its protective effect against intestinal mucosa damage caused by 5-FU chemotherapy [10]. Thus, this property further highlights the anti-inflammatory effect that the CIDCA 133 strain can exert on the host. 
The commensal and probiotic bacteria must also act in symbiosis with the host to promote its beneficial effects. The host provides a stable habitat for these microorganisms while providing them with beneficial nutrients [92,93]. In this context, the presence of five metabolic islands (MI), seven symbiotic Islands (SI), and genes related to proteolytic activity in the CIDCA 133 genome (e.g., OppA, pepC pepI, pepA, PrtB) highlights the ability of this strain to capture and metabolize dairy proteins during the fermentation process. An organized proteolytic system has also been identified in other Lactobacillus species, such as L. reuteri [94,95], L. helveticus [96], and Lactiplantibacillus pentosus (L. pentosus) [97].

The proteolytic activity of probiotic bacteria during the fermentation process is much responsible for bioactive peptides production [98] and other compounds, such as vitamins [99] and Short Chain Fatty Acids (SCFA) [100,101], which, besides improving the sensory characteristics of dairy products [102,103], promote beneficial effects to the host due to its antioxidant and immunomodulatory activity. The beneficial effects of fermented formulations by probiotic bacteria, such as L. rhamnosus GG [104], L. delbrueckii CNRZ327 [105], L. plantarum [11], L. paracasei BL23, and P. freudenreichii 138 [9], has been reported due to their effectiveness for preventing enteric infection, and the intestinal inflammation and histological damage in murine models of colitis and mucositis disease. The beneficial effects of dairy fermented product by CIDCA 133 were previously reported in a murine model of mucositis [10], evidencing, therefore, the intrinsic and healthy symbiotic relationship between the administration of this probiotic strain and the host.

Another relevant property attributed to CIDCA 133 is its ability to inhibit enteropathogenic and other probiotic bacteria, an effect previously reported by Kociubinski et al. [22] and Hugo et al. [24] for other pathogens. The authors observed inhibition of CIDCA 133 against food spoilage and pathogenic bacteria B. subtilis, B. cereus, P. aeruginosa, and enterohemorrhagic E. coli O157:H7, and attributed all above inhibitory effects to the probiotic strain's capacity to produce organic compounds, such as lactate.

The inhibitory effects of probiotics against pathogenic bacteria are also related to the production of bacteriocins. This property, as previously demonstrated by Oliveira et al. [106], showed that L. rhamnosus L156.4 inhibits the growth of pathogenic bacteria and other Lactobacillus by both the production of organic acids present in the strain supernatant and to the antibacterial activity of the bacteriocin enterocin A, whose gene was identified in its genome through BAGEL3 web server [106]. These findings support the present study results due to identifying the gene encoding the bacteriocins helveticin J and enterolysin $\mathrm{A}$, and CIDCA $133^{\prime}$ s ability to inhibit acid-resistance bacteria with a probiotic profile, such as L. delbrueckii CNRZ327 and L. paracasei BL23.

In conclusion, the genome-scale analysis of health-promoting probiotic CIDCA 133 elucidated many important functional roles of this strain. CIDCA 133 showed a broader repertoire of genes involved with molecular mechanisms related to its interaction with host, survival, adaptation, and immunostimulatory ability. The molecular bases attributed to the anti-inflammatory profile of CIDCA 133 can be associated with secreted and membrane/exposed to surface proteins. This is the first probiogenomics study of CIDCA 133, validated with in vitro and in vivo experiments, reinforcing that this strain is a highly effective probiotic, providing valuable benefits to the host.

Supplementary Materials: The following are available online at https:/ / www.mdpi.com/article/10 $.3390 /$ microorganisms9040829/s1, Table S1: List of human proteins used to protein-protein interaction; Table S2: Proteolytic system predicted in L. delbrueckii CIDCA 133 genome; Table S3: Genomic Islands identified in the L. delbrueckii CIDCA 133 genome by Gipsy software; Table S4: Proteins of L. delbrueckii CIDCA 133 sublocated on Membrane, surface exposed (PSE) and Secreted predicted by SurfG+ software; Table S5: Predicted proteins of L. delbrueckii CIDCA 133 with high probably adhesion capacity predicted by Vaxign software; Table S6: InterSPPI human and L. delbrueckii CIDCA 133 protein-protein interaction. 
Author Contributions: Conceptualization, L.C.L.d.J. and F.F.A.; methodology, L.C.L.d.J., F.F.A., T.d.J.S., N.D.C.-R., R.P., B.B., data curation, T.d.J.S.; Writing-Original draft preparation, L.C.L.d.J.; Writing-Review and editing, F.F.A., T.d.J.S., M.M.D., P.M.-A., V.A.; supervision, V.A.; funding acquisition, V.A. All authors have read and agreed to the published version of the manuscript.

Funding: This research was funded by Conselho Nacional de Desenvolvimento Científico e Tecnológico (CNPq), grant number 312045/2020-4.

Institutional Review Board Statement: The study was conducted according to the guidelines of the Brazilian College of Animal Experimentation (COBEA), and approved by the Local Animal Experimental Ethics Committee of Universidade Federal de Minas Gerais (CEUA-UFMG) (Protocol $n^{\circ} 112 / 2020 ; 08$ August 2020).

Informed Consent Statement: Not applicable.

Data Availability Statement: Complete genome sequences used for these analyses are available from the GenBank, NCBI.

Acknowledgments: The authors would like to acknowledge the Pró-Reitoria de Pesquisa-Universidade Federal de Minas Gerais, Rede de Ciências Ômicas (RECOM), the Conselho Nacional de Desenvolvimento Científico e Tecnológico (CNPq), Coordenação de Aperfeiçoamento de Pessoal de Nível Superior (CAPES) and Fundação de Amparo à Pesquisa do Estado de Minas Gerais (FAPEMIG) for their financial support and fellowships. We would also like to acknowledge the Centro de Investigación y Desarrollo en Criotecnología de Alimentos (CIDCA) and Pablo F. Pérez of Universidad Nacional de La Plata-Argentina for bacteria strain supply.

Conflicts of Interest: The authors declare no conflict of interest.

\section{References}

1. De Angelis, M.; Gobbetti, M. Lactobacillus SPP.: General Characteristics. In Reference Module in Food Science; Elsevier: Amsterdam, The Netherlands, 2016; pp. 72-90.

2. Salvetti, E.; Torriani, S.; Felis, G.E. The Genus Lactobacillus: A Taxonomic Update. Probiotics Antimicrob. Proteins 2012, 4, 217-226. [CrossRef]

3. Kandler, O. Carbohydrate metabolism in lactic acid bacteria. Antonie Van Leeuwenhoek 1983, 49, 209-224. [CrossRef] [PubMed]

4. Pot, B.; Felis, G.E.; Bruyne, K. De; Tsakalidou, E.; Papadimitriou, K.; Leisner, J.; Vandamme, P. The genus Lactobacillus. In Lactic Acid Bacteria; John Wiley \& Sons, Ltd.: Chichester, UK, 2014; pp. 249-353.

5. Santos Rocha, C.; Gomes-Santos, A.C.; Garcias Moreira, T.; de Azevedo, M.; Diniz Luerce, T.; Mariadassou, M.; Longaray Delamare, A.P.; Langella, P.; Maguin, E.; Azevedo, V.; et al. Local and Systemic Immune Mechanisms Underlying the Anti-Colitis Effects of the Dairy Bacterium Lactobacillus delbrueckii. PLoS ONE 2014, 9, e85923. [CrossRef]

6. Galdeano, C.M. Stimulation of Innate Immune Cells Induced by Probiotics: Participation of Toll-Like Receptors. J. Clin. Cell. Immunol. 2015, 6. [CrossRef]

7. Fedorak, R.N.; Feagan, B.G.; Hotte, N.; Leddin, D.; Dieleman, L.A.; Petrunia, D.M.; Enns, R.; Bitton, A.; Chiba, N.; Paré, P.; et al The Probiotic VSL\#3 Has Anti-inflammatory Effects and Could Reduce Endoscopic Recurrence After Surgery for Crohn's Disease. Clin. Gastroenterol. Hepatol. 2015, 13, 928-935.e2. [CrossRef] [PubMed]

8. Bjarnason, I.; Sission, G.; Hayee, B. A randomised, double-blind, placebo-controlled trial of a multi-strain probiotic in patients with asymptomatic ulcerative colitis and Crohn's disease. Inflammopharmacology 2019, 27, 465-473. [CrossRef] [PubMed]

9. Cordeiro, B.F.; Oliveira, E.R.; da Silva, S.H.; Savassi, B.M.; Acurcio, L.B.; Lemos, L.; Alves, J.d.L.; Carvalho Assis, H.; Vieira, A.T.; Faria, A.M.C.; et al. Whey Protein Isolate-Supplemented Beverage, Fermented by Lactobacillus casei BL23 and Propionibacterium freudenreichii 138, in the Prevention of Mucositis in Mice. Front. Microbiol. 2018, 9. [CrossRef]

10. De Jesus, L.C.L.; Drumond, M.M.; de Carvalho, A.; Santos, S.S.; Martins, F.S.; Ferreira, Ê.; Fernandes, R.S.; de Barros, A.L.B.; do Carmo, F.L.R.; Perez, P.F.; et al. Protective effect of Lactobacillus delbrueckii subsp. Lactis CIDCA 133 in a model of 5 Fluorouracil-Induced intestinal mucositis. J. Funct. Foods 2019, 53, 197-207. [CrossRef]

11. Acurcio, L.B.; Bastos, R.W.; Sandes, S.H.d.C.; Guimarães, A.C.d.C.; Alves, C.G.; Reis, D.C.d.; Wuyts, S.; Nunes, Á.C.; Cassali, G.D.; Lebeer, S.; et al. Protective effects of milk fermented by Lactobacillus plantarum B7 from Brazilian artisanal cheese on a Salmonella enterica serovar Typhimurium infection in BALB/c mice. J. Funct. Foods 2017, 33, 436-445. [CrossRef]

12. Arreguin-Nava; Hernández-Patlán; Solis-Cruz; Latorre; Hernandez-Velasco; Tellez; El-Ashram; Hargis; Tellez-Isaias Isolation and Identification of Lactic Acid Bacteria Probiotic Culture Candidates for the Treatment of Salmonella enterica Serovar Enteritidis in Neonatal Turkey Poults. Animals 2019, 9, 696. [CrossRef]

13. Hill, C.; Guarner, F.; Reid, G.; Gibson, G.R.; Merenstein, D.J.; Pot, B.; Morelli, L.; Canani, R.B.; Flint, H.J.; Salminen, S.; et al. The International Scientific Association for Probiotics and Prebiotics consensus statement on the scope and appropriate use of the term probiotic. Nat. Rev. Gastroenterol. Hepatol. 2014, 11, 506-514. [CrossRef] 
14. McFarland, L.V.; Evans, C.T.; Goldstein, E.J.C. Strain-Specificity and Disease-Specificity of Probiotic Efficacy: A Systematic Review and Meta-Analysis. Front. Med. 2018, 5. [CrossRef]

15. Douillard, F.P.; Ribbera, A.; Järvinen, H.M.; Kant, R.; Pietilä, T.E.; Randazzo, C.; Paulin, L.; Laine, P.K.; Caggia, C.; von Ossowski, I.; et al. Comparative Genomic and Functional Analysis of Lactobacillus casei and Lactobacillus rhamnosus Strains Marketed as Probiotics. Appl. Environ. Microbiol. 2013, 79, 1923-1933. [CrossRef]

16. Zhang, W.; Wang, J.; Zhang, D.; Liu, H.; Wang, S.; Wang, Y.; Ji, H. Complete Genome Sequencing and Comparative Genome Characterization of Lactobacillus johnsonii ZLJ010, a Potential Probiotic With Health-Promoting Properties. Front. Genet. 2019, 10. [CrossRef] [PubMed]

17. Verce, M.; De Vuyst, L.; Weckx, S. Comparative genomics of Lactobacillus fermentum suggests a free-living lifestyle of this lactic acid bacterial species. Food Microbiol. 2020, 89, 103448. [CrossRef]

18. Ventura, M.; Turroni, F.; van Sinderen, D. Probiogenomics as a tool to obtain genetic insights into adaptation of probiotic bacteria to the human gut. Bioengineered 2012, 3, 73-79. [CrossRef]

19. Arellano, K.; Vazquez, J.; Park, H.; Lim, J.; Ji, Y.; Kang, H.-J.; Cho, D.; Jeong, H.W.; Holzapfel, W.H. Safety Evaluation and Whole-Genome Annotation of Lactobacillus plantarum Strains from Different Sources with Special Focus on Isolates from Green Tea. Probiotics Antimicrob. Proteins 2020, 12, 1057-1070. [CrossRef] [PubMed]

20. Gilbert, C.; Atlan, D.; Blanc, B.; Portailer, R.; Germond, J.E.; Lapierre, L.; Mollet, B. A new cell surface proteinase: Sequencing and analysis of the prtB gene from Lactobacillus delbruekii subsp. bulgaricus. J. Bacteriol. 1996, 178, 3059-3065. [CrossRef] [PubMed]

21. El Kafsi, H.; Binesse, J.; Loux, V.; Buratti, J.; Boudebbouze, S.; Dervyn, R.; Kennedy, S.; Galleron, N.; Quinquis, B.; Batto, J.-M.; et al. Lactobacillus delbrueckii ssp. lactis and ssp. bulgaricus: A chronicle of evolution in action. BMC Genom. 2014, 15, 407. [CrossRef] [PubMed]

22. Kociubinski, G.L.; Pérez, P.F.; Añón, M.C.; de Antoni, G.L. A Method of Screening for Highly Inhibitory Lactic Acid Bacteria. J. Food Prot. 1996, 59, 739-745. [CrossRef] [PubMed]

23. Kociubinski, G.; Pérez, P.; de Antoni, G. Screening of Bile Resistance and Bile Precipitation in Lactic Acid Bacteria and Bifidobacteria. J. Food Prot. 1999, 62, 905-912. [CrossRef]

24. Hugo, A.A.; Kakisu, E.; De Antoni, G.L.; Pérez, P.F. Lactobacilli antagonize biological effects of enterohaemorrhagic Escherichia coli in vitro. Lett. Appl. Microbiol. 2008, 46, 613-619. [CrossRef]

25. Rolny, I.S.; Tiscornia, I.; Racedo, S.M.; Pérez, P.F.; Bollati-Fogolín, M. Lactobacillus delbrueckii subsp lactis CIDCA 133 modulates response of human epithelial and dendritic cells infected with Bacillus cereus. Benef. Microbes 2016, 7, 749-760. [CrossRef]

26. Hugo, A.A.; Rolny, I.S.; Romanin, D.; Pérez, P.F. Lactobacillus delbrueckii subsp. lactis (strain CIDCA 133) stimulates murine macrophages infected with Citrobacter rodentium. World J. Microbiol. Biotechnol. 2017, 33, 48. [CrossRef]

27. Hugo, A.A.; De Antoni, G.L.; Pérez, P.F. Lactobacillus delbrueckii subsp lactis (strain CIDCA 133) resists the antimicrobial activity triggered by molecules derived from enterocyte-like Caco-2 cells. Lett. Appl. Microbiol. 2010, 50, 335-340. [CrossRef]

28. Hugo, A.A.; Tymczyszyn, E.E.; Gómez-Zavaglia, A.; Pérez, P.F. Effect of human defensins on lactobacilli and liposomes. J. Appl. Microbiol. 2012, 113, 1491-1497. [CrossRef]

29. De, S.; Kaur, G.; Roy, A.; Dogra, G.; Kaushik, R.; Yadav, P.; Singh, R.; Datta, T.K.; Goswami, S.L. A Simple Method for the Efficient Isolation of Genomic DNA from Lactobacilli Isolated from Traditional Indian Fermented Milk (dahi). Indian J. Microbiol. 2010, 50, 412-418. [CrossRef] [PubMed]

30. Simon Andrews FastQC: A Quality Control Tool for High Throughput Sequence Data. Available online: http://www. bioinformatics.babraham.ac.uk/projects/fastqc (accessed on 2 December 2020).

31. Hernandez, D.; Francois, P.; Farinelli, L.; Osteras, M.; Schrenzel, J. De novo bacterial genome sequencing: Millions of very short reads assembled on a desktop computer. Genome Res. 2008, 18, 802-809. [CrossRef] [PubMed]

32. Gurevich, A.; Saveliev, V.; Vyahhi, N.; Tesler, G. QUAST: Quality assessment tool for genome assemblies. Bioinformatics 2013, 29, 1072-1075. [CrossRef]

33. Galardini, M.; Biondi, E.G.; Bazzicalupo, M.; Mengoni, A. CONTIGuator: A bacterial genomes finishing tool for structural insights on draft genomes. Source Code Biol. Med. 2011, 6, 11. [CrossRef] [PubMed]

34. de Sá, P.H.C.G.; Miranda, F.; Veras, A.; de Melo, D.M.; Soares, S.; Pinheiro, K.; Guimarães, L.; Azevedo, V.; Silva, A.; Ramos, R.T.J. GapBlaster-A Graphical Gap Filler for Prokaryote Genomes. PLoS ONE 2016, 11, e0155327. [CrossRef] [PubMed]

35. Guizelini, D.; Raittz, R.T.; Cruz, L.M.; Souza, E.M.; Steffens, M.B.R.; Pedrosa, F.O. GFinisher: A new strategy to refine and finish bacterial genome assemblies. Sci. Rep. 2016, 6, 34963. [CrossRef] [PubMed]

36. QIAGEN CLC Genomics Workbench. Available online: www.clcbio.com/products/clc-genomics-workbench (accessed on 2 December 2020).

37. Tatusova, T.; DiCuccio, M.; Badretdin, A.; Chetvernin, V.; Nawrocki, E.P.; Zaslavsky, L.; Lomsadze, A.; Pruitt, K.D.; Borodovsky, M.; Ostell, J. NCBI prokaryotic genome annotation pipeline. Nucleic Acids Res. 2016, 44, 6614-6624. [CrossRef]

38. Carattoli, A.; Zankari, E.; García-Fernández, A.; Voldby Larsen, M.; Lund, O.; Villa, L.; Møller Aarestrup, F.; Hasman, H. In Silico Detection and Typing of Plasmids using PlasmidFinder and Plasmid Multilocus Sequence Typing. Antimicrob. Agents Chemother. 2014, 58, 3895-3903. [CrossRef]

39. Richter, M.; Rosselló-Móra, R.; Oliver Glöckner, F.; Peplies, J. JSpeciesWS: A web server for prokaryotic species circumscription based on pairwise genome comparison. Bioinformatics 2016, 32, 929-931. [CrossRef] 
40. Barinov, A.; Loux, V.; Hammani, A.; Nicolas, P.; Langella, P.; Ehrlich, D.; Maguin, E.; van de Guchte, M. Prediction of surface exposed proteins in Streptococcus pyogenes, with a potential application to other Gram-positive bacteria. Proteomics 2009, 9, 61-73. [CrossRef]

41. Araujo, F.A.; Barh, D.; Silva, A.; Guimarães, L.; Ramos, R.T.J. Go Feat: A rapid web-based functional annotation tool for genomic and transcriptomic data. Sci. Rep. 2018, 8, 1794. [CrossRef] [PubMed]

42. He, Y.; Xiang, Z.; Mobley, H.L.T. Vaxign: The First Web-Based Vaccine Design Program for Reverse Vaccinology and Applications for Vaccine Development. J. Biomed. Biotechnol. 2010, 2010, 297505. [CrossRef]

43. Liu, M.; Bayjanov, J.R.; Renckens, B.; Nauta, A.; Siezen, R.J. The proteolytic system of lactic acid bacteria revisited: A genomic comparison. BMC Genom. 2010, 11, 36. [CrossRef]

44. Broadbent, J.R.; Cai, H.; Larsen, R.L.; Hughes, J.E.; Welker, D.L.; De Carvalho, V.G.; Tompkins, T.A.; Ardö, Y.; Vogensen, F.; De Lorentiis, A.; et al. Genetic diversity in proteolytic enzymes and amino acid metabolism among Lactobacillus helveticus strains. J. Dairy Sci. 2011, 94, 4313-4328. [CrossRef]

45. Papadimitriou, K.; Alegría, Á.; Bron, P.A.; de Angelis, M.; Gobbetti, M.; Kleerebezem, M.; Lemos, J.A.; Linares, D.M.; Ross, P.; Stanton, C.; et al. Stress Physiology of Lactic Acid Bacteria. Microbiol. Mol. Biol. Rev. 2016, 80, 837-890. [CrossRef]

46. Oliveira, L.C.; Saraiva, T.D.L.; Silva, W.M.; Pereira, U.P.; Campos, B.C.; Benevides, L.J.; Rocha, F.S.; Figueiredo, H.C.P.; Azevedo, V.; Soares, S.C. Analyses of the probiotic property and stress resistance-related genes of Lactococcus lactis subsp. lactis NCDO 2118 through comparative genomics and in vitro assays. PLoS ONE 2017, 12, e0175116. [CrossRef]

47. Fontana, A.; Falasconi, I.; Molinari, P.; Treu, L.; Basile, A.; Vezzi, A.; Campanaro, S.; Morelli, L. Genomic Comparison of Lactobacillus helveticus Strains Highlights Probiotic Potential. Front. Microbiol. 2019, 10. [CrossRef]

48. Wu, P.; An, J.; Chen, L.; Zhu, Q.; Li, Y.; Mei, Y.; Chen, Z.; Liang, Y. Differential Analysis of Stress Tolerance and Transcriptome of Probiotic Lacticaseibacillus casei Zhang Produced from Solid-State (SSF-SW) and Liquid-State (LSF-MRS) Fermentations. Microorganisms 2020, 8, 1656. [CrossRef] [PubMed]

49. Soares, S.C.; Geyik, H.; Ramos, R.T.J.; de Sá, P.H.C.G.; Barbosa, E.G.V.; Baumbach, J.; Figueiredo, H.C.P.; Miyoshi, A.; Tauch, A.; Silva, A.; et al. GIPSy: Genomic island prediction software. J. Biotechnol. 2016, 232, 2-11. [CrossRef]

50. Alikhan, N.-F.; Petty, N.K.; Ben Zakour, N.L.; Beatson, S.A. BLAST Ring Image Generator (BRIG): Simple prokaryote genome comparisons. BMC Genom. 2011, 12, 402. [CrossRef]

51. van Heel, A.J.; de Jong, A.; Song, C.; Viel, J.H.; Kok, J.; Kuipers, O.P. BAGEL4: A user-friendly web server to thoroughly mine RiPPs and bacteriocins. Nucleic Acids Res. 2018, 46, W278-W281. [CrossRef] [PubMed]

52. Lian, X.; Yang, S.; Li, H.; Fu, C.; Zhang, Z. Machine-Learning-Based Predictor of Human-Bacteria Protein-Protein Interactions by Incorporating Comprehensive Host-Network Properties. J. Proteome Res. 2019, 18, 2195-2205. [CrossRef]

53. Shannon, P. Cytoscape: A Software Environment for Integrated Models of Biomolecular Interaction Networks. Genome Res. 2003, 13, 2498-2504. [CrossRef] [PubMed]

54. Singhal, N.; Maurya, A.K.; Mohanty, S.; Kumar, M.; Virdi, J.S. Evaluation of Bile Salt Hydrolases, Cholesterol-Lowering Capabilities, and Probiotic Potential of Enterococcus faecium Isolated From Rhizosphere. Front. Microbiol. 2019, 10. [CrossRef]

55. Farias, N.; Soares, M.; Gouveia, E. Enhancement of the viability of Lactobacillus rhamnosus ATCC 7469 in passion fruit juice: Application of a central composite rotatable design. LWT-Food Sci. Technol. 2016, 71, 149-154. [CrossRef]

56. Xu, Y.; Tian, Y.; Cao, Y.; Li, J.; Guo, H.; Su, Y.; Tian, Y.; Wang, C.; Wang, T.; Zhang, L. Probiotic Properties of Lactobacillus paracasei subsp. paracasei L1 and Its Growth Performance-Promotion in Chicken by Improving the Intestinal Microflora. Front. Physiol. 2019, 10. [CrossRef] [PubMed]

57. Somashekaraiah, R.; Shruthi, B.; Deepthi, B.V.; Sreenivasa, M.Y. Probiotic Properties of Lactic Acid Bacteria Isolated From Neera: A Naturally Fermenting Coconut Palm Nectar. Front. Microbiol. 2019, 10. [CrossRef]

58. Volynets, V.; Rings, A.; Bárdos, G.; Ostaff, M.J.; Wehkamp, J.; Bischoff, S.C. Intestinal barrier analysis by assessment of mucins, tight junctions, and $\alpha$-defensins in healthy C57BL/6J and BALB/cJ mice. Tissue Barriers 2016, 4, e1208468. [CrossRef] [PubMed]

59. Giulietti, A.; Overbergh, L.; Valckx, D.; Decallonne, B.; Bouillon, R.; Mathieu, C. An Overview of Real-Time Quantitative PCR: Applications to Quantify Cytokine Gene Expression. Methods 2001, 25, 386-401. [CrossRef] [PubMed]

60. Song, M.-K.; Park, M.-Y.; Sung, M.-K. 5-Fluorouracil-Induced Changes of Intestinal Integrity Biomarkers in BALB/C Mice. J. Cancer Prev. 2013, 18, 322-329. [CrossRef] [PubMed]

61. Chang, C.-W.; Lee, H.-C.; Li, L.-H.; Chiang Chiau, J.-S.; Wang, T.-E.; Chuang, W.-H.; Chen, M.-J.; Wang, H.-Y.; Shih, S.C.; Liu, C.-Y.; et al. Fecal Microbiota Transplantation Prevents Intestinal Injury, Upregulation of Toll-Like Receptors, and 5-Fluorouracil/Oxaliplatin-Induced Toxicity in Colorectal Cancer. Int. J. Mol. Sci. 2020, 21, 386. [CrossRef] [PubMed]

62. Zheng, L.; Zhang, Y.-L.; Dai, Y.-C.; Chen, X.; Chen, D.-L.; Dai, Y.-T.; Tang, Z.-P. Jianpi Qingchang decoction alleviates ulcerative colitis by inhibiting nuclear factor- $\mathrm{kB}$ activation. World J. Gastroenterol. 2017, 23, 1180. [CrossRef]

63. Sun, Z.; Harris, H.M.B.; McCann, A.; Guo, C.; Argimón, S.; Zhang, W.; Yang, X.; Jeffery, I.B.; Cooney, J.C.; Kagawa, T.F.; et al. Expanding the biotechnology potential of lactobacilli through comparative genomics of 213 strains and associated genera. Nat. Commun. 2015, 6, 8322. [CrossRef] [PubMed]

64. Inglin, R.C.; Meile, L.; Stevens, M.J.A. Clustering of Pan- and Core-genome of Lactobacillus provides Novel Evolutionary Insights for Differentiation. BMC Genom. 2018, 19, 284. [CrossRef] [PubMed]

65. Lee, J.-H.; Halgerson, J.S.; Kim, J.-H.; O'Sullivan, D.J. Comparative Sequence Analysis of Plasmids from Lactobacillus delbrueckii and Construction of a Shuttle Cloning Vector. Appl. Environ. Microbiol. 2007, 73, 4417-4424. [CrossRef] [PubMed] 
66. Arnold, J.W.; Simpson, J.B.; Roach, J.; Kwintkiewicz, J.; Azcarate-Peril, M.A. Intra-species Genomic and Physiological Variability Impact Stress Resistance in Strains of Probiotic Potential. Front. Microbiol. 2018, 9. [CrossRef]

67. Chen, L.; Gu, Q.; Li, P.; Chen, S.; Li, Y. Genomic analysis of Lactobacillus reuteri WHH 1689 reveals its probiotic properties and stress resistance. Food Sci. Nutr. 2019, 7, 844-857. [CrossRef]

68. Yao, W.; Yang, L.; Shao, Z.; Xie, L.; Chen, L. Identification of salt tolerance-related genes of Lactobacillus plantarum D31 and T9 strains by genomic analysis. Ann. Microbiol. 2020, 70, 10. [CrossRef]

69. Shehata, M.G.; El Sohaimy, S.A.; El-Sahn, M.A.; Youssef, M.M. Screening of isolated potential probiotic lactic acid bacteria for cholesterol lowering property and bile salt hydrolase activity. Ann. Agric. Sci. 2016, 61, 65-75. [CrossRef]

70. Albarracín, W.; Sánchez, I.C.; Grau, R.; Barat, J.M. Salt in food processing; usage and reduction: A review. Int. J. Food Sci. Technol. 2011, 46, 1329-1336. [CrossRef]

71. Bautista-Gallego, J.; Arroyo-López, F.N.; Durán-Quintana, M.C.; Garrido-Fernández, A. Individual Effects of Sodium, Potassium, Calcium, and Magnesium Chloride Salts on Lactobacillus pentosus and Saccharomyces cerevisiae Growth. J. Food Prot. 2008, 71, 1412-1421. [CrossRef] [PubMed]

72. Gandhi, A.; Shah, N.P. Effect of salt on cell viability and membrane integrity of Lactobacillus acidophilus, Lactobacillus casei and Bifidobacterium longum as observed by flow cytometry. Food Microbiol. 2015, 49, 197-202. [CrossRef] [PubMed]

73. Vélez, M.P.; De Keersmaecker, S.C.J.; Vanderleyden, J. Adherence factors of Lactobacillus in the human gastrointestinal tract. FEMS Microbiol. Lett. 2007, 276, 140-148. [CrossRef] [PubMed]

74. Turpin, W.; Humblot, C.; Noordine, M.-L.; Thomas, M.; Guyot, J.-P. Lactobacillaceae and Cell Adhesion: Genomic and Functional Screening. PLoS ONE 2012, 7, e38034. [CrossRef] [PubMed]

75. Le Maréchal, C.; Peton, V.; Plé, C.; Vroland, C.; Jardin, J.; Briard-Bion, V.; Durant, G.; Chuat, V.; Loux, V.; Foligné, B.; et al. Surface proteins of Propionibacterium freudenreichii are involved in its anti-inflammatory properties. J. Proteom. 2015, 113, 447-461. [CrossRef]

76. Deutsch, S.-M.; Mariadassou, M.; Nicolas, P.; Parayre, S.; Le Guellec, R.; Chuat, V.; Peton, V.; Le Maréchal, C.; Burati, J.; Loux, V.; et al. Identification of proteins involved in the anti-inflammatory properties of Propionibacterium freudenreichii by means of a multi-strain study. Sci. Rep. 2017, 7, 46409. [CrossRef]

77. do Carmo, F.L.R.; Rabah, H.; Cordeiro, B.F.; Silva, S.H. da; Pessoa, R.M.; Fernandes, S.O.A.; Cardoso, V.N.; Gagnaire, V.; Deplanche, M.; Savassi, B.; et al. Probiotic Propionibacterium freudenreichii requires SlpB protein to mitigate mucositis induced by chemotherapy. Oncotarget 2019, 10, 7198-7219. [CrossRef] [PubMed]

78. Ashida, N.; Yanagihara, S.; Shinoda, T.; Yamamoto, N. Characterization of adhesive molecule with affinity to Caco-2 cells in Lactobacillus acidophilus by proteome analysis. J. Biosci. Bioeng. 2011, 112, 333-337. [CrossRef] [PubMed]

79. Taverniti, V.; Stuknyte, M.; Minuzzo, M.; Arioli, S.; De Noni, I.; Scabiosi, C.; Cordova, Z.M.; Junttila, I.; Hämäläinen, S.; Turpeinen, H.; et al. S-Layer Protein Mediates the Stimulatory Effect of Lactobacillus helveticus MIMLh5 on Innate Immunity. Appl. Environ. Microbiol. 2013, 79, 1221-1231. [CrossRef] [PubMed]

80. Rocha-Ramírez, L.M.; Pérez-Solano, R.A.; Castañón-Alonso, S.L.; Moreno Guerrero, S.S.; Ramírez Pacheco, A.; García Garibay, M.; Eslava, C. Probiotic Lactobacillus Strains Stimulate the Inflammatory Response and Activate Human Macrophages. J. Immunol. Res. 2017, 2017, 4607491. [CrossRef]

81. Kawai, T.; Akira, S. Signalling to NF-кB by Toll-like receptors. Trends Mol. Med. 2007, 13, 460-469. [CrossRef] [PubMed]

82. Galdeano, C.M.; Perdigón, G. The Probiotic Bacterium Lactobacillus casei Induces Activation of the Gut Mucosal Immune System through Innate Immunity. Clin. Vaccine Immunol. 2006, 13, 219-226. [CrossRef]

83. Rajput, I.R.; Ying, H.; Yajing, S.; Arain, M.A.; Weifen, L.; Ping, L.; Bloch, D.M.; Wenhua, L. Saccharomyces boulardii and Bacillus subtilis B10 modulate TLRs and cytokines expression patterns in jejunum and ileum of broilers. PLoS ONE 2017, 12, e0173917. [CrossRef]

84. Schreiber, S.; Nikolaus, S.; Hampe, J. Activation of nuclear factor kappa B in inflammatory bowel disease. Gut 1998, 42, 477-484. [CrossRef]

85. Burkitt, M.D.; Hanedi, A.F.; Duckworth, C.A.; Williams, J.M.; Tang, J.M.; O’Reilly, L.A.; Putoczki, T.L.; Gerondakis, S.; Dimaline, R.; Caamano, J.H.; et al. NF-кB1, NF-kB2 and c-Rel differentially regulate susceptibility to colitis-associated adenoma development in C57BL/ 6 mice. J. Pathol. 2015, 236, 326-336. [CrossRef] [PubMed]

86. Han, Y.M.; Koh, J.; Kim, J.W.; Lee, C.; Koh, S.-J.; Kim, B.; Lee, K.L.; Im, J.P.; Kim, J.S. NF-kappa B activation correlates with disease phenotype in Crohn's disease. PLoS ONE 2017, 12, e0182071. [CrossRef] [PubMed]

87. Justino, P.F.C.; Melo, L.F.M.; Nogueira, A.F.; Morais, C.M.; Mendes, W.O.; Franco, A.X.; Souza, E.P.; Ribeiro, R.A.; Souza, M.H.L.P.; Soares, P.M.G. Regulatory role of Lactobacillus acidophilus on inflammation and gastric dysmotility in intestinal mucositis induced by 5-fluorouracil in mice. Cancer Chemother. Pharmacol. 2015, 75, 559-567. [CrossRef] [PubMed]

88. Oh, N.S.; Joung, J.Y.; Lee, J.Y.; Kim, Y. Probiotic and anti-inflammatory potential of Lactobacillus rhamnosus 4B15 and Lactobacillus gasseri 4M13 isolated from infant feces. PLoS ONE 2018, 13, e0192021. [CrossRef]

89. Kawano, M.; Miyoshi, M.; Miyazaki, T. Lactobacillus helveticus SBT2171 Induces A20 Expression via Toll-Like Receptor 2 Signalling and Inhibits the Lipopolysaccharide-Induced Activation of Nuclear Factor-kappa B and Mitogen-Activated Protein Kinases in Peritoneal Macrophages. Front. Immunol. 2019, 10. [CrossRef] [PubMed]

90. Podolsky, D.K.; Gerken, G.; Eyking, A.; Cario, E. Colitis-Associated Variant of TLR2 Causes Impaired Mucosal Repair Because of TFF3 Deficiency. Gastroenterology 2009, 137, 209-220. [CrossRef] [PubMed] 
91. Dheer, R.; Santaolalla, R.; Davies, J.M.; Lang, J.K.; Phillips, M.C.; Pastorini, C.; Vazquez-Pertejo, M.T.; Abreu, M.T. Intestinal Epithelial Toll-Like Receptor 4 Signalling Affects Epithelial Function and Colonic Microbiota and Promotes a Risk for Transmissible Colitis. Infect. Immun. 2016, 84, 798-810. [CrossRef] [PubMed]

92. Buron-Moles, G.; Chailyan, A.; Dolejs, I.; Forster, J.; Mikš, M.H. Uncovering carbohydrate metabolism through a genotypephenotype association study of 56 lactic acid bacteria genomes. Appl. Microbiol. Biotechnol. 2019, 103, 3135-3152. [CrossRef] [PubMed]

93. Visconti, A.; Le Roy, C.I.; Rosa, F.; Rossi, N.; Martin, T.C.; Mohney, R.P.; Li, W.; de Rinaldis, E.; Bell, J.T.; Venter, J.C.; et al. Interplay between the human gut microbiome and host metabolism. Nat. Commun. 2019, 10, 4505. [CrossRef] [PubMed]

94. Saulnier, D.M.; Santos, F.; Roos, S.; Mistretta, T.-A.; Spinler, J.K.; Molenaar, D.; Teusink, B.; Versalovic, J. Exploring Metabolic Pathway Reconstruction and Genome-Wide Expression Profiling in Lactobacillus reuteri to Define Functional Probiotic Features. PLoS ONE 2011, 6, e18783. [CrossRef]

95. Kristjansdottir, T.; Bosma, E.F.; Branco dos Santos, F.; Özdemir, E.; Herrgård, M.J.; França, L.; Ferreira, B.; Nielsen, A.T.; Gudmundsson, S. A metabolic reconstruction of Lactobacillus reuteri JCM 1112 and analysis of its potential as a cell factory. Microb. Cell Fact. 2019, 18, 186. [CrossRef]

96. Griffiths, M.W.; Tellez, A.M. Lactobacillus helveticus: The proteolytic system. Front. Microbiol. 2013, 4. [CrossRef] [PubMed]

97. Abriouel, H.; Pérez Montoro, B.; Casimiro-Soriguer, C.S.; Pérez Pulido, A.J.; Knapp, C.W.; Caballero Gómez, N.; Castillo-Gutiérrez, S.; Estudillo-Martínez, M.D.; Gálvez, A.; Benomar, N. Insight into Potential Probiotic Markers Predicted in Lactobacillus pentosus MP-10 Genome Sequence. Front. Microbiol. 2017, 8. [CrossRef] [PubMed]

98. Singh, B.P.; Vij, S. Growth and bioactive peptides production potential of Lactobacillus plantarum strain C2 in soy milk: A LC-MS/MS based revelation for peptides biofunctionality. LWT 2017, 86, 293-301. [CrossRef]

99. De Angelis, M.; Bottacini, F.; Fosso, B.; Kelleher, P.; Calasso, M.; Di Cagno, R.; Ventura, M.; Picardi, E.; van Sinderen, D.; Gobbetti, M. Lactobacillus rossiae, a Vitamin B12 Producer, Represents a Metabolically versatile Species within the Genus Lactobacillus. PLoS ONE 2014, 9, e107232. [CrossRef] [PubMed]

100. Sun, M.; Wu, W.; Chen, L.; Yang, W.; Huang, X.; Ma, C.; Chen, F.; Xiao, Y.; Zhao, Y.; Ma, C.; et al. Microbiota-derived short-chain fatty acids promote Th1 cell IL-10 production to maintain intestinal homeostasis. Nat. Commun. 2018, 9, 3555. [CrossRef]

101. Nagpal, R.; Wang, S.; Ahmadi, S.; Hayes, J.; Gagliano, J.; Subashchandrabose, S.; Kitzman, D.W.; Becton, T.; Read, R.; Yadav, H. Human-origin probiotic cocktail increases short-chain fatty acid production via modulation of mice and human gut microbiome. Sci. Rep. 2018, 8, 12649. [CrossRef] [PubMed]

102. Cruz, A.G.; Cadena, R.S.; Walter, E.H.M.; Mortazavian, A.M.; Granato, D.; Faria, J.A.F.; Bolini, H.M.A. Sensory Analysis: Relevance for Prebiotic, Probiotic, and Synbiotic Product Development. Compr. Rev. Food Sci. Food Saf. 2010, 9, 358-373. [CrossRef]

103. Dimitrellou, D.; Salamoura, C.; Kontogianni, A.; Katsipi, D.; Kandylis, P.; Zakynthinos, G.; Varzakas, T. Effect of Milk Type on the Microbiological, Physicochemical and Sensory Characteristics of Probiotic Fermented Milk. Microorganisms 2019, 7, 274. [CrossRef]

104. Yoda, K.; Miyazawa, K.; Hosoda, M.; Hiramatsu, M.; Yan, F.; He, F. Lactobacillus GG-fermented milk prevents DSS-induced colitis and regulates intestinal epithelial homeostasis through activation of epidermal growth factor receptor. Eur. J. Nutr. 2014, 53, 105-115. [CrossRef]

105. Plé, C.; Breton, J.; Richoux, R.; Nurdin, M.; Deutsch, S.-M.; Falentin, H.; Hervé, C.; Chuat, V.; Lemée, R.; Maguin, E.; et al. Combining selected immunomodulatory Propionibacterium freudenreichii and Lactobacillus delbrueckii strains: Reverse engineering development of an anti-inflammatory cheese. Mol. Nutr. Food Res. 2016, 60, 935-948. [CrossRef] [PubMed]

106. Oliveira, L.d.C.; Silveira, A.M.M.; Monteiro, A.d.S.; dos Santos, V.L.; Nicoli, J.R.; Azevedo, V.A.d.C.; Soares, S.d.C.; Dias-Souza, M.V.; Nardi, R.M.D. In silico Prediction, in vitro Antibacterial Spectrum, and Physicochemical Properties of a Putative Bacteriocin Produced by Lactobacillus rhamnosus Strain L156.4. Front. Microbiol. 2017, 8. [CrossRef] [PubMed] 